\title{
Political Speech, Sexual Harassment, and a Captive Workforce
}

\author{
Jessica M. Karner $\dagger$
}

The impact of sexual harassment on female workers and the optimal response to sexual harassment are increasingly subjects of popular and academic debate as society attempts to balance gender equality with selfexpression. Aimed at eradicating gender discrimination in the workplace, hostile environment sexual harassment law prohibits speech or conduct that creates an intimidating, hostile, or offensive work environment. While most find the goal of hostile environment law unassailable, it has developed with little heed to the First Amendment. The result is the dual risk of infringement of free speech and invalidation of hostile environment harassment law. This Comment demonstrates that the current hostile environment standard violates traditional First Amendment principles and doctrine. After exploring the existing exceptions to First Amendment protection, the author concludes that none operates to save hostile environment law. However, consideration of the values underlying the First Amendment suggests that some regulation of harassing speech is consistent with the principle of free speech. The author argues that harassing speech in the workplace should be regulable when it infringes greatly on the captive listener and contributes little to self-governance. Consistent with this rationale, this Comment argues that the captive audience doctrine, traditionally applied only in the home, should be expanded into the workplace. However, the author would not apply the doctrine to allow regulation of political workplace speech, which, by definition, contributes to self-governance. Finally, to complement the First Amendment analysis offered, this Comment sets forth a hostile environment sexual harassment standard, adapted from the current standard, that attempts to best balance free speech values with the goal of equality.

Copyright $\odot 1995$ California Law Review, Inc.

$\dagger$ B.A. 1991, University of California, Berkeley; J.D. candidate 1995, Boalt Hall School of Law, University of California, Berkeley. I would like to thank Professors Jesse Choper and Robert Post for challenging me with their thoughtful comments on earker drafts; any shortcomings are my own. I would also like to thank the editors and staff of the Californic Law Review. 
"The law of equality and the law of freedom of speech are on a collision course in this country."

\section{INTRODUCTION}

What lias been referred to as the "hate speecli dilemma" is the tension between two fundamental values in our society: equality and freedom of speech. ${ }^{2}$ One could argue that there is no real tension. ${ }^{3}$ As long as we have laws preventing actual discrimmation, people can and should be able to say anything they want without disrupting equality. After all, aren't the best remedies for evil counsels good ones?

One problem with the argument agamst all hate speech regulation is that, in particular settings, hate speecl can cause harms that may not be addressed by more speech. ${ }^{4}$ Not only may the good counsels relied upon to counter evil ones never come, but society might determine that the harms caused by hate speech are intolerable in particular places. In sucl settings, some speech regulation may be justifiable in order to reach the ideal of meaningful equality. ${ }^{5}$ But how mucli regulation is too much? And what should be the doctrinal justification for sucli regulation?

This Comment will focus on a particular kind of hate speech: genderbased hate speech in the workplace. ${ }^{6}$ This type of speecli is one of the targets of workplace sexual harassment regulations, an area of law that has

1. Catharine A. MacKinnon, OnLy Words 71 (1993).

2. See, e.g., Toni M. Massaro, Equality and Freedom of Expression: The Hate Speech Dilemma, 32 WM. \& MARY L. REv. 211 (1991). In rejecting arguments made by the proponents of hate speecb regulation, Arthur Schlesinger, Jr., writes:

This theory of the Constitution as the bulwark not of individual but of group rights undermines our current civil liberties doctrine. But that theory has behind it potent emotions-tbe cmotions of Holocaust survivors at Skokie, the emotions of women long subjected to discrimination, harassment and abuse, the emotions of all oppressed and harried minorities. Arthur Schlesinger, Jr., Multiculturalism and the Bill of Rights, 46 ME. L. Rev. 191, 203 (1994).

3. Nadine Strossen makes this argument in Nadine Strossen, In the Defense of Freedom and Equality: The American Civil Liberties Union Past, Present, and Future, 29 HARv. C.R.-C.L. L. Rev. 143,149 (1994).

4. One study on demographics and free expression revealed that "[f]emales, in general, cxhibit greater fear of most forms of retribution and greater reluctance to speak out," and that "[b]lacks are dramatically less likely to speak out than whites." ROBERT O. WyATT, FreE EXPRESSION AND THE American Public: A Survey Commemorating the 200th Anniversary of the First Amendment 63-64 (1991). If women and African-Americans are more reluctant to speak out than males or whites, it seems likely that they may not counter discriminatory speech with more speech.

5. Of course, regulation of specch involves state action, wbile the reluctance of an individual to respond to hate speech does not. For this reason, while the goal of equality may support some regulation of hate speech as a normative matter, the regulation must be justified by First Amendment doctrine as well. Broadly speaking, that is the topic of this Comment.

6. For an analysis of hate speech regulations on college campuses, see Charles R. Lawrence Ill, If He Hollers Let Him Go: Regulating Racist Speech on Campus, 1990 Duke L.J. 431.

Men can, of course, suffer sexual harassment. See, e.g., EEOC Compliance Manual $\S 615.2(b)(1)(1993)$. This Comment will focus on the sexual harassment of women. However, the First Amendment analysis of harassment law applies equally to sexual larassment of men, as well as to racial, religious, and national origin harassment, which are also prohibited by Title VIl. 42 U.S.C. $\$ 2000$ e2(a)(1) (1988). 
developed quickly over the last two decades. ${ }^{7}$ The goal of these regulations has been to achieve actual equality within the workplace. Now that the workplace is formally open to women, the law has necessarily directed itself toward ensuring that the workplace truly becomes a place of equal opportunity, that women are not allowed in only to be forced back out by on-the-job harassment. ${ }^{8}$

Workplace harassment law has developed with little attention, however, to First Amendment concerns. ${ }^{9}$ This mattention creates the danger that speech that should be protected forms the basis for liability. It also creates the danger that, when the First Amendment is raised nore seriously as a defense to sexual harassment claims, ${ }^{10}$ the baby will be thrown out with the bath water - that too much sexual harassment law will be mvalidated. Both advocates of equality and proponents of free speech, ${ }^{11}$ then, lave an interest in the adoption of a sexual harassment standard that is sensitive to First Amendment concerns. This Comment proposes such a standard, ${ }^{12}$ as well as a modification of First Amendment doctrine that

7. See Barbara lindemann \& Davi D. Kadue, Sexual Harassment in Employment Law 3 (1992) (" $[N]$ ot until 1976 did a court recognize that Title VIl forbids the form of sex discrimination that is now called sexual harassment, and only in 1986 did the Supreme Court . . . finally establish that Title VII prohibits harassment in employment even if the harassment does not cause a direct financial injury.") (citation \& footnotes omitted).

8. See, e.g., Marcy Strauss, Sexist Speech in the Workplace, 25 HARv. C.R.-C.L. L. REv. 1, 14 (1990) ("In essence, sexist speech reinstitutionalizes barriers in the workplace based on gender.").

9. Id. at 3 (commenting on the dearth of attention paid to First Amendment issues raised by regulation of offensive language in the workplace); see also United States v. X-Citement Video, Inc., 982 F.2d 1285, 1296 n.7 (9th Cir. 1992) (Kozinski, J., dissenting) ("Because First Amendment defenses were rarely raised, harassment law evolved with hitle concern for free speech, and some workplace harassment cases seem suspect on First Amendment grounds.'), rev'd 115 S. Ct. 464 (1994).

10. Reently, a federal district court sustained an "as applied" challenge to a fire department policy banning Playboy and similar publications from all workplace locations. Johnson v. County of Los Angeles Fire Dep't, 865 F. Supp. 1430, 1442 (C.D. Cal. 1994). First Amendment freedom of expression has been raised as a defeuse in a small number of sexual harassment cases as well. See, e.g., Robinson v. Jacksonville Shipyards, Inc., 760 F. Supp. 1486, 1534-36 (M.D. Fla. 1991) (denying a First Amendment defense because employers had disavowed an intent to express themselves through sexually oriented pictures or verbal harassment by employees, because the pictures and harassment were not protected speech since "they act[ed] as discriminatory conduct in the form of a hostile work environment," because workplace speech regulation is a valid time, place, and manner regulation, and because the female workers at defendant's worksite constituted a captive audience); Jew v. University of Iowa, 749 F. Supp. 946, 961 (S.D. Iowa 1990) (denying a free speech defense because rumors about plaintiff's sexual activity with department head were false, so that the First Amendment could not immunize the university from Title VII liability for a hostile work environment); EEOC v. Sage Realty Corp., 507 F. Supp. 599, 610 (S.D.N.Y. 1981) (rejecting a freedom of expression defeuse because defendant had "disclaimed any intention to express itself artistically by dressing its lobby personnel in sexually revealing outfits"). Religious freedom has also been raised, albeit unsuceessfully, as a defense to sexual harassment. See Jill Hodges, Ex-Pastor May Sue For Harassment, Star Tribune, June 18, 1991, at 3B.

11. These arc, of course, not necessarily two distinct groups. For example, members of the ACLU "all share a commitment to free spcech and equality principles." Nadine Strossen, Regulating Workplace Sexual Harassment and Upholding the First Amendment-Avoiding a Collision, 37 VILL. L. REv. 757, 757 (1992).

12. See infra Part VI. 
allows for regulation of most workplace harassment, without eroding all protection of workplace speech. ${ }^{13}$

Part I of this Comment briefly describes the development and current state of hostile environment sexual harassment law, which prohibits speech or conduct that creates a hostile, intimidating, or offensive work environment. ${ }^{14}$ Part II discusses the ways in which hostile environment law violates traditional First Amendment doctrine. Part III explores existing exceptions to First Amendment protections and concludes that none operates to save hostile environment law. Part IV addresses the normative question of whether speech that contributes to a hostile work environment should, as a policy matter, be regulated. This Part concludes, based on underlying First Amendment values, that soine regulation of sexually harassing speech should be allowed. Part V suggests an expansion of the captive audience doctrine, a current exception to the First Amendment, to encompass the regulation of soine workplace speech. Finally, Part VI proposes a modification of the current hostile environment standard that conforms more closely with the requirements of the First Amendment generally, and with the expansion of the captive audience doctrine advanced in Part V.

Hostile Environment Sexual Harassment Law

The concept of sexual harassment as a legal wrong with accompanying legal remedies is a relatively recent developinent. Courts first recognized in the late 1970s that Title VII of the Civil Rights Act of 1964 prohibited sexual harassment. ${ }^{15}$ Although there are other sources of possible legal liability for wrongs that can be described under the heading sexual harassinent, ${ }^{16}$ this Comment will focus on the legal rights and remedies developed under Title VII.

\section{A. The Development of Hostile Environment Sexual Harassment Law Under Title VII}

Title VII, which inakes it an "unlawful employment practice for an einployer ... to discriminate against any individual with respect to his coinpensation, terms, conditions, or privileges of employment, because of such individual's . . . sex," does not mention sexual harassment. ${ }^{17}$ Instead, it is the guidelines developed by the Equal Employment Opportunity

13. See infra Part V.

14. See infra Part I.A.

15. Lisa A. Brown, Title VII and Beyond: Developments in the Law of Sexual Harassment, Houston Law., Sept.-Oct. 1992, at 24, 24 (citing Barnes v. Castle, 561 F.2d 983 (D.C. Cir. 1977)).

16. For example, the tort of intentional inflietion of emotional distress. E.g., Toretto v. I.B. Diffusion, L.P., 126 Lab. Cas. (CCH) I 57,471 (N.D. 1ll. Nov. 10, 1992).

17. 42 U.S.C. $\$ 2000 \mathrm{e}-2(a)(1)(1988)$. The section also applies to discrimination based on race, color, religion, and national origin. Although much of the analysis offered here can apply to hostile 
Commission (EEOC) to enforce Title VII that explicitly prohibit sexual harassment as a form of sex discrimination. The regulations define sexual harassment as "[u]nwelcome sexual advances, requests for sexual favors, and other verbal or physical conduct of a sexual nature," when submission to such conduct is made a condition or term of employment or the basis for employment decisions, or when "such conduct has the purpose or effect of unreasonably interfering with an individual's work performance or creating an intimidating, hostile, or offensive working environment."18

Based on the EEOC Guidelines, courts have recognized two distinct forms of sexual harassment as violations of Title VII: hostile environment sexual harassment, described below, and quid pro quo harassment, in which the victim is asked to submit to the harassment as a condition of receiving job benefits, such as a promotion, or to avoid being fired or suffering other denials of earned economic benefits. ${ }^{19}$ Like the crinie of extortion, ${ }^{20}$ this type of overt threat raises no First Amendment probleins. As seen below, however, hostile environment harassment goes much further in imposing liability based on speech.

In the definitive case to date, Meritor Savings Bank $v$. Vinson, ${ }^{21}$ the Supreme Court approved the EEOC Guidelines and held that a plaintiff could establish a violation of Title VII by proving that sex-based harassment "has created a hostile or abusive work environment."22 The Court rejected the argument that " 'purely psychological aspects of the workplace environment" " were not covered by Title VII. ${ }^{23}$ Thus, a plaintiff need not show economic or tangible loss to establish hostile environment harassment. ${ }^{24}$ The Court clarified, however, that not all workplace "conduct that may be described as 'liarassinent' " violates Title VII. Under Meritor, sexual harassment rises to the level of hostile environment discrimination only when it is "sufficiently severe or pervasive "to alter the conditions of [the victim's] einployment and create an abusive working environment." "2s

environment claims based on these other protected categories, this Comment will focus only on hostile environment sexual harassment.

18. 29 C.F.R. $\$ 1604.11$ (a)(1993) (emphasis added).

19. See, e.g., Karibian v. Columbia University, 14 F.3d 773, 777 (2d Cir.) ("[T]o establish a prima facie case of quid pro quo harassment, a plaintiff must present evidence that she was subject to unwelcome sexual conduct, and that her reaction to that conduct was then used as the basis for decisions affecting the compensation, terms, conditions or privileges of her employment."), cert. denied, I14 S. Ct. 2693 (1994).

20. See, e.g., Rankin v. McPherson, 483 U.S. 378, 398 (Scalia, J., dissenting) (noting that extortion is not entitled to "any First Amendment protection at all").

21. 477 U.S. 57 (1986).

22. Id. at 66 .

23. See id. at 64 (quoting Brief for Petitioner).

24. Id.

25. Id. at 67 (alteration in original) (quoting Henson v. Dundee, $682 \mathrm{~F} .2 \mathrm{~d} 897,904$ (I lth Cir. 1982)).

An employer is not automatically hable for hostile environment harassment. Rather, the liability of the employer is determined by common-law agency principles. Generally, the employer is liable for co- 
The Court did not discuss in any detail the parameters of this standard, perhaps because the harassing conduct alleged by the plaintiff was so severe. ${ }^{26}$ However, the Court did state that the "phrase 'terms, conditions, or privileges of employment' evinces a congressional intent 'to strike at the entire spectrum of disparate treatment of men and women' in employment."27 Moreover, the Court approvingly cited precedent relied on by the EEOC which held that "Title VII affords einployees the right to work in an environment free from discriminatory intimidation, ridicule, and insult."28 Thus, the Court seeined to indicate that the sexual harassinent standard should be applied generously to advance the goals of Title VII, but did little to aid lower courts in the specific application of the standard.

A final noteworthy aspect of the hostile environment standard is that the trier of fact must determine the existence of sexual harassment froin the "record as a whole" and the "totality of the circumstances."29 Thus, a lower court must apply the loosely defined standard of Meritor to an unconstrained set of facts and circumstances. Perhaps the most definitive statement that may be inade about the standard of liability is that the line that divides the merely offensive from the actionable under Title VII hostile environment law is somewhere between isolated sexual epithets, which will not create an abusive or hostile environment, ${ }^{30}$ and abuse severe enough to drive a victim from her job, which is inore than what is necessary to ereate a hostile environment. ${ }^{31}$

\section{B. Lower Courts' Application of Hostile Environment Sexual Harassment Law}

Given the great degree of latitude provided by the Supreme Court's formulation of hostile environment law, lower courts have developed

worker harassment if she knew, or reasonably should have known, about the harassment and failed to take adequate steps to remedy the harassment. See Hall v. Gus Construction, 842 F.2d 1010, 1013 (8th Cir. 1988); cf. Koteher v. Rosa \& Sullivan Appliance Ctr., Inc., 957 F.2d 59, 63 (2d Cir. 1992) (asserting that plaintiff must prove that the employer either provided no reasonable avenue for complaint or knew of the harassment and failed to remedy it). If the harasser is a supervisor, the employcr may be liable upon a lesser showing of culpability. See, e.g., Karibian v. Columbia University, 14 F.3d 773, 779-80 (2d Cir.) (holding that an employer is liable for a hostile environment created by a supervisor where the supervisor used his actual or apparent authority to accomphish the harassment), cert. denied, 114 S. Ct. 2693 (1994). at 60 .

26. The plaintiff alleged, among other things, that she had been forcibly raped. Meritor, 477 U.S.

27. Id. at 64 (internal quotations omitted) (quoting Los Angeles Dep't of Water \& Power v. Manhart, 435 U.S. 702, 707 n.13 (1978) (quoting Sprogis v. United Air Lines, Inc., 444 F.2d 1194, 1198 (7th Cir.), cert. denied, 404 U.S. 991 (1971))).

28. Id. at 65 (eiting 45 Fed. Reg. 74,676 (1980)).

29. The EEOC made this explicit in its guidelines. 29 C.F.R. $\S 1604.11$ (b) (1994). In Meritor, the Court discussed this element of the guidelines approvingly. 477 U.S. at 69 .

30. Meritor, 477 U.S. at 67 (citing Rogers v. EEOC, 454 F.2d 234, 238 (5th Cir. 1971), cert. denied, 406 U.S. 957 (1972)).

31. Id. at 64 (stating that 'the language of Title VII is not limited to 'economic' or 'tangible' discrimination'). 
widely varying interpretations of exactly how severe or pervasive harassment must be to establish liability. The lower courts have even reached differing definitions of what constitutes harassment in the first place.

For example, the U.S. Courts of Appeals have split over whether a reasonable person (without reference to gender) or a reasonable woman standard should be applied to analyze a woman's claim of harassment. The Ninth Circuit has held that "a female plaimtiff states a prima facie case of hostile environment sexual harassment when she alleges conduct which a reasonable woman would consider sufficiently severe or pervasive to alter the conditions of employment and create an abusive working environment." ${ }^{\text {"32 }}$ The Sixth and Eighth Circuits have also adopted a reasonable woman standard, ${ }^{33}$ and the Third Circuit has adopted a reasonable person of the same sex as the victim standard. ${ }^{34}$ The Fourth, Fifth, and Seventh Circuits have held that the objective component of a hostile environment claim should be judged from the perspective of a reasonable person. ${ }^{35}$ The Supreme Court's recent decision in Harris v. Forklift Systems, Inc. ${ }^{36}$ employed a "reasonable person" standard, but did not hold that such a standard was required. ${ }^{37}$ The lower court in Harris had employed a reasonable woman standard; the Court quoted the lower court's use of the standard without commenting on its appropriateness. ${ }^{38}$

The circuits have also disagreed over whether discrimmation must be intentional to be actionable under Title VII. The Third Circuit has held that to bring a successful claim the employee must have suffered "intentional discrimination because of [her] sex."39 In Ellison $v$. Brady, the Ninth Circuit determined that its reasonable woman, or "reasonable victim," standard precluded a requirement of intent:

Well-intentioned compliments by co-workers or supervisors can forin the basis of a sexual harassment cause of action if a reasonable victim of the same sex as the plaintiff would consider the comments sufficiently severe or pervasive to alter a condition of employment

32. Ellison v. Brady, 924 F.2d 872, 879 (9th Cir. 1991) (footnotes omitted). The court noted that a hostile environment claim by a male would be judged by a reasonable man standard. Id. at 879 n.11.

33. See Burns v. McGregor Elec. Indus., Inc., 989 F.2d 959, 962 n.3 (8th Cir. 1993) (discussing the choices made in other circuits and adopting a reasonable woman standard); Yates v. Avco Corp. 819 F.2d 630, 637 (6th Cir. 1987) (applying a reasonable woman standard).

34. See Andrews v. City of Philadelphia, 895 F.2d 1469, 1482 (3d Cir. 1990) (adopting a reasonable person of the same sex standard).

35. See King v. Board of Regents, 898 F.2d 533, 537 (7th Cir. 1990) (applying reasonable person standard); Paroline v. Unisys Corp. 879 F.2d 100, 105 (4th Cir. 1989) (same), vacated and remanded, 900 F.2d 27 (4th Cir. 1990) (en banc); Waltman v. International Paper Co., 875 F.2d 468, 476 (5th Cir. 1989) (same).

36. 114 S. Ct. 367 (1993).

37. Id. at 371.

38. Id. at 370 .

39. Andrews v. City of Philadelphia, 895 F.2d 1469, 1482 (3d Cir. 1990) (emphasis added). 
and create an abusive working environment. That is because Title

VII is not a fault-based tort scheme. ${ }^{40}$

The EEOC Guidelines on sexual harassment state that when verbal or physical conduct of a sexual nature "has the purpose or effect"41 of creating a hostile working environment, it constitutes sexual harassment in violation of Title VII. Althougli the issue is not settled, the EEOC's language, coupled with the fact that neither Meritor nor Harris mention intent, suggests that imtent is currently not required.

Harris resolved a circuit split regarding the severity and nature of harm to the plaimtiff that must be shown before an employer is liable for hostile environment sexual liarassment. Several circuits had required that the hostile or offensive environment seriously affect the victim's psychological well-being. ${ }^{42}$ In Ellison, the Nimth Circuit expressly rejected that requirement. ${ }^{43}$ The Supreme Court agreed with the Nimth Circuit's position, holding that Title VII is not limited to conduct seriously affecting the plaintiff's, or a reasonable person's, psychological well-bemg. ${ }^{44}$

Fimally, lower courts have disagreed over whether the speech or conduct has to be sexual in nature, as suggested by the language of the EEOC regulations, or can simply be based on the sex of the victim. ${ }^{45}$ Harris seems to have resolved this conflict by citing non-sexual statements as contributing to the hostile environment. ${ }^{46}$ Theresa Harris, a manager at Forklift Systems, Inc., was harassed by the company president, Charles Hardy. Hardy made comments to Harris such as "You're a woman, what do you know" and "We need a man as the rental manager." He also called her "a dumb ass woman."47 These comments, while based on Harris' sex, are clearly not sexual in nature.

Despite the Supreme Court's resolution in Harris of some uncertainties regarding the Meritor standard, the standard itself still allows for differ-

40. 924 F.2d 872, 880 (9th Cir. 1991) (footnote omitted).

41. 29 C.F.R. $\$ 1604.11$ (a) (1994) (emphasis added).

42. See, e.g., Andrews, 895 F.2d at 1482 (stating that the abusive work environment must be " 'severe enough to affect the psychological stability" " of the victim) (quoting Vance v. Southern Bell Tel. \& Tel. Co., 863 F.2d 1503, 1510 (11th Cir. 1989)); Rabidue v. Osceola Refining Co., 805 F.2d 611, 622 (6th Cir. 1986) (finding plaintiff failed to meet burden of proof where co-worker's "obsccnities, although annoying, were not so startling as to have affected seriously the psyches of the plaintiff or other female employees"), cert. denied, 107 S. Ct. 1983 (1987); Downes v. FAA, 775 F.2d 288, 292 (Fed. Cir. 1985) (requiring serious effect on victim's psychological well-being).

43. 924 F.2d at $877-78$ ("It is the harasser's conduct which must be pervasive or severe, not the alteration in the conditious of employment.").

44. Harris v. Forklift Sys., Inc., 114 S. Ct. 367, 371 (1993). Although the parties presented and briefed the issue, the Court did not discuss the First Amendment implications of its holding. The Court seemed to aeknowledge that it was dcclining to reach the issue. Id. ("We necd not answer today all the potential questions [the hostile environment harassment test] raises ....").

45. 29 C.F.R. $\$ 1604.11$ (a) (1994) ("verbal or physical conduct of a sexual nature"); see also e.g. Downes, 775 F.2d at 290 (requiring harassment be sexual in nature); Hicks v. Gates Rubber Co., 833 F.2d 1406, 1415 (10th Cir. 1987) (contra).

46. See Harris, 114 S. Ct. at 369.

47. Id. 
ing interpretations by lower courts. The central question in any hostile environment sexual harassment case remains whether the harassment has risen to the level of creating an abusive or hostile environment. By its nature, this standard is imprecise and allows for latitude in application.

For example, different lower courts have held similar types of conduct to contribute, and not to contribute, to a hostile work environment. In Robinson v. Jacksonville Shipyards, Inc. ${ }^{48}$ the court held that pornography posted at the workplace contributed to a hostile work environment. ${ }^{49}$ But in Rabidue v. Osceola Refining Co., ${ }^{50}$ a court held that workplace pornography had a "de minimis effect" on the work environment. ${ }^{51}$ Courts have also held similar types of speech to contribute, and not to contribute, to a hostile work environment. ${ }^{52}$ While many of these differences can be explained by the fact that hostile work environment claims are, by their nature, fact intensive inquiries, that does not preclude the possibility of a better, nnore administrable standard.

II

\section{How Hostile Environment LaW VIolates the FIRST AMENDMENT}

\section{A. Workplace Speech Rights}

A threshold inatter in considering the constitutionality of hostile environment sexual harassment law is whether there is, or should be, a "workplace speech" exception to the First Amendment. In this Section, I first address the arguments of other commentators who have concluded that

48. 760 F. Supp. 1486 (M.D. Fla. 1991).

49. Id. at 1524-25. Another court held that, even assuming that pornography posted at the worksite constituted harassment, the employer's prompt action in having the material removed precluded a finding of liability. Tunis v. Corning Glass Works, 747 F. Supp. $951,958-59$ (S.D.N.Y. 1990), aff'd without op., 930 F.2d 910 (2d Cir. 1991).

50. 805 F.2d 611 (6th Cir. 1986), cert. denied, 481 U.S. 1041 (1987).

51. Id. at 622. The court in Rabidue took into account the pervasiveness of "written and pictorial erotica" in our society. In that context, the court explained, male employees' displays of pictures of naked or scantily clad women could not substantially affect the work environment. Id. The Rabidue court evaluated the evidence under a standard that required the work environment to seriously affect the plaintiff's psychological well-being for a cause of action to be stated. Id. In Harris, the Supreme Court refuted this standard, holding that conduct need not seriously affect a plaintiff's psychological wellbeing to be actionable. Harris v. Forklift Sys., Inc., 114 S. Ct. 367, 371 (1993). However, in hight of the Rabidue court's characterization of the effect of pornography on the workplace environment as "de minimis," it seems the result of the case may have been the same even if the court had applied the proper standard.

52. For example, comments made by a supervisor to a female employee about the size and appearance of the breasts and buttocks of other women who worked for the company were deemed "minor" in terms of severity by one court. Thompson v. Campbell, 845 F. Supp. 665, 673-74 (D. Minn. 1994) (granting summary judgment for defendants under a Minnesota employment discrimination statute interpreted to incorporate Title VII hostile environment standards). Comments "referring to women generally in terms of their body parts" have also been found to contribute to a hostile work environment, as part of an overall sexualization of that environment. Jenson v. Eveleth Taconite Co., 824 F. Supp. 847,880 (D. Minn. 1993). 
workplace speech does, or should, receive less First Amendment protection than speech in general. Second, I examine Supreme Court doctrine involving both public and private workplace speech rights. I conclude that it is incorrect, both as a policy and a doctrinal matter, to except all workplace speech from First Amendment protection.

\section{Response to Other Commentators}

Several commentators have argued that workplace speech is unprotected, or at least regulable, for various reasons. I will address the strongest of these arguments first. In an article focusing on democratic selfgovernance as a value underlying the First Amendment, Professor Robert Post has argued that

even if the first amendment were to immunize from legal regulation the circulation of certain racist ideas in newspapers, it would not follow that the expression of those same ideas could not be restrained by the government within the workplace, where an image of dialogue among autonomous self-governing citizens would be patently out of place..$^{53}$

Professor Post does not explaim why such an image would be so out of place, but his assumption seems to be that worksites are not a forum for political speech. ${ }^{54}$ This assuniption is questionable. An employee in this country remains at all times a member of a democracy, witl all of the freedoms and attributes that entails. It is dangerous to label workplace speech ${ }^{55}$ as inherently outside of the "public" speech necessary for democratic selfgovernance. For many, the workplace may be the primary location of social interaction, and it is arguable that today more political speecli occurs at the workplace than in the public square. While employees are less autonomous (and lience are presunied to contribute less to the goal of democratic self-

53. Robert C. Post, Racist Speech, Democracy, and the First Amendment, 32 WM. \& MARY L. REv. 267, 289 (1991). Professor Post's claim about nonpublic (including workplace) speech is not that it is entirely unprotected by the First Amendenent, but rather that if it is protected, "it will be on the basis of constitutional values other than democratic self-governance." Id. at $289 \mathrm{n} .113$.

54. Professor Post cites cases allowing regulation of racially harassing speech and conduct, but does not explain the significance of these cases. Id. at $289 \mathrm{n.112}$ (citing Rogers v. EEOC, 454 F.2d 234, 237-38 (5th Cir. 1971), cert. denied, 406 U.S. 957 (1972); EEOC v. Murphy Motor Freight Lines, 488 F. Supp. 381, 385 (D. Minn. 1980)). If they show simply that the work environment may be rcgulatcd, then citing them begs the question. If the descriptions of harassing speech and conduct in the cases are meant to show that no pohitical deliberation is being carried out at the workplace, the citcd cases are insufficient to establish that proposition.

Professor Post may also mean that, because employees are by definition "governed" by their employer while they are on the job, they may not be simultaneously autonomous and self-govcrning. I would argue (although this seems immune to empirical proof on either side) that a person may be "governed" as an employee, and yct remain autonomous with regard to personal views and expressions.

55. Or at least most workplace speeeh. Professor Post does concede that some workplacc speech may lie within the public discourse, and hence may be proteeted. Id. at $289 \mathrm{n} .112$ (citing Connick v. Myers, 46 I U.S. 138, 149 (1983); Givhan v. Western Line Consol. Sch. Dist., 439 U.S. 410, 415-16 (1979)). 
governance) while on the job than at other times, in the sense that they are subject to their employer's control, they remain at a basic level autonomous citizens. ${ }^{56}$ Moreover, political speech at the workplace contributes to selfgovernance equally, one would think, to political speecl that occurs elsewhere.

Professor Post believes that regulation in the public workplace is acceptable because it is a managerial, rather than a governmental, form of regulation. 57 The difference between the two "turns on the priority accorded to proposed objectives." 58 Managerial authority refers to the government's management of its own internal affairs, while governance authority refers to the government's management of the general public. ${ }^{59}$ According to Professor Post, where government is exercising its managerial authority, it has inore leeway to regulate speecli because that regulation may be "necessary for the achievement of its legitimate institutional ends."

This argument is persuasive in the context of government's regulation of its own employees. ${ }^{61}$ When government regulates the private-sector workplace to achieve equality within the workplace, however, it is acting in a governmental, not a managerial capacity. The Supreme Court has recognized this distinction: "the State has interests as an employer in regulating the speech of its employees that differ significantly from those it possesses in connection with regulation of the speech of the citizenry in general." Thus, Professor Post's management-governance distinction applies only to governmental employees and cannot serve as a justification for sexual harassment regulations in the private sector.

Another scholar, Professor Rodney Smolla, has suggested that workplace speech may be regulated because it is part of a "transactional set-

56. This duality of roles was recognized by Chief Judge Newman of the Second Circuit. He noted that the speech of public employees may be simultaneously on a matter or private interest and on a matter of public concern for purposes of the Connick test. Saulpaugh v. Monroe Community Hosp., 4 F.3d 134, 147 (2d Cir. 1993) (Newman, C.J., concurring), cert. denied, 114 S. Ct. 1189 (1994). For a description of the Connick test, see infra Part II.A.2.b.

57. See generally Robert C. Post, Between Governance and Management: The History and Theory of the Public Forum, 34 UCLA L. REv. I7I3, 1717 (1987) (discussing the possible reformulation of public forum doctrine that focuses on "the nature of the government authority in question," rather than on the character of the government property under consideration).

58. Id. at 1789 .

59. Id. at I784-85.

60. Id. at $\mathrm{I} 783$.

61. It is unclear whether Professor Post's distinction between governance and management would place hostile environment regulations in the arena of governance or management. The workplace, even the private sector workplace, is a place with specific institutional objectives. This suggests when government regulates within the workplace it is acting in a "managerial" capacity. See id. at 1789. However, the centraI goal of Title VII is to advance equality within the workplace, not to further the institutionaI goals of the workplace. Therefore, even under Professor Post's reformulation of the public forum doctrine, it is arguable that speech regulation in the workplace is governmental in nature, and therefore that workplace speech should be protected.

62. Pickering v. Board of Educ., 391 U.S. 563, 568 (1968). 
ting."63 A statement of transaction, as defined by Professor Smolla, is "the use of language to propose or conclude some form of transaction." type of speech, Professor Smolla claims, deserves only a low level of protection. Professor Smolla does not explam the connection between transactional speech and transactional settings, but simply asserts that speech that is part of a transactional setting may be regulated. He then explains that the "only first amendment inquiry is into the bona fides of the purported transactional rationale. As long as we are satisfied that the rule is indeed genumely transactional, it normally will be upheld."65

Presumably, a rule is "genuinely transactional" when it governs transactional speech, or operates in a transactional setting. By creating a category of "transactional settings," however, this line of analysis assumes that all workplace speech is "low-value" (and hence regulable) transactional speech: ${ }^{66}$ not statements of opinion or fact, but simply proposals for soine form of transaction. In reality, much workplace speech is simply conversation among colleagues, unrelated to the jobs being accomplished. Workplace speech should not be grouped automatically in a way that leaves it all unprotected, or protected at a very low level.

Finally, a student commentator has argued that einployees im the private sector simply do not enjoy First Amendment protection. ${ }^{67}$ Amy Horton bases her conclusion that private-sector employees have no free speech rights on the at-will employment doctrine. Because this doctrine allows private employers to fire employees for any reason or no reason, she argues, "private sector management is free to dictate what an employee may and may not say by wielding the ever-powerful threat of dismissal."

63. Rodney A. Smolla, Rethinking First Amendment Assumptions About Racist and Sexist Speech, 47 WASH. \& LeE L. REV. 171, 197 (1990).

64. Id. at 186 .

65. Id. at 197 .

66. To the extent Professor Smolla's analysis can be limited to quid pro quo harassment, which can be considered a "transaction" accomplished through speech, it has logical force. However, because no First Amendment issue is raised by the regulation of quid pro quo harassment, this aspect of his analysis is not relevant to the issues addressed in this Comment.

But Professor Smolla does not seem to limit his argument to quid pro quo harassment: "Because much of our concem about racist and sexist speech does in fact arise in such transactional settings, controls that are conscientiously aimed at eliminating racism and sexism in those transactional relationships should be constitutional if properly tailored." Id. at 187 (emphasis added). This argument seems to encompass all workplace speech.

Professor Smolla does not argue that transactional speech should lack all protection. For example, commercial speech, which Professor Smolla considers to be transactional speech combined with the additional element of information, opinion, or entertainment, does receive some degree of First Amendment protection. Id. (citing Ccntral Hudson Gas \& Elec. Corp. v. Public Serv. Comm'n, 447 U.S. 557 (1980)). However, whatever level of protection should be afforded transactional speech, it would not preclude regulating sexist and racist speech in the workplace. Id.

67. Amy Horton, Comment, Of Supervision, Centerfolds, and Censorship: Sexual Harassment, the First Amendment, and the Contours of Title VII, 46 U. MiAMI L. REv. 403, 408 (1991).

68. Id. at 421 . 
Horton concludes that, under this doctrine and the state action doctrine, the First Amendment is largely irrelevant in private sector workplaces. ${ }^{69}$

In support of Horton's thesis is the argument that, by imposing liability on the employer, the government is not suppressing einployee speech at all. The government regulates only the employer; it is the employer who creates the guidelimes governing employee speecl. Because government action is necessary to trigger the protection of the First Amendment, hostile environment law raises no constitutional issue as far as employee speecli is concerned.

This argument suffers froin two flaws. First, the availability of injunctive relief, discussed infra Part III.B.3, belies any notion that hostile environment harassment law does not allow for the direct governmental restriction of speech. A court can force an employer to regulate employee speech and behavior when the employer has failed to do so to the court's satisfaction. Second, by threatening liability in the first place, the governinent forces the eniployer to regulate einployee speech. As one commentator succinctly wrote, "[t] $]$ he government simply cannot avoid First Amendment scrutiny by using the threat of legal liability to coerce a private party into implementing the speech restriction on its behalf."70

The failing in Horton's conclusion is by now apparent: the First Amendment protects against government control of speech. ${ }^{71}$ Horton is correct insofar as she argues that a private employer inay regulate employee speech without raising First Amendment concerns. However, government regulation of speech presents a fundamentally different issue. With regard to government action, workplace speech rights are clearly not diminished by the at-will employment doctrine.

Arguments that the First Amendment does not protect workplace speech raise serious policy concerns. Many people in this country do not attend college, or the political meetings at the local "town square." For such people, interchange while on the job may be the only "political" speech in which they engage. ${ }^{72}$ A categorical workplace-speech exception

69. Id. at 419 .

70. Eugene Volokh, Comment, Freedom of Speech and Workplace Harassment, 39 UCLA L. Rev. 1791, 1818 (1992).

71. U.S. Const. amend. I ("Congress shall make no law ... abridging the freedom of speech ....") (emphasis added). The First Amendment is, of course, made applicable to the states through the Fourteenth Amendment. See, e.g., Lamb's Chapel v. Center Moriches Union Free Sch. Dist., 113 S. Ct. 2141, 2144 (1993).

72. For the purposes of this Comment's analysis and proposed standard, political speech is defined as speech that contributes to self-governance. Generally, this includes "core" political speech-speech rcgarding pohtics or governmental issues-and speech about social issues, such as gender equality and social roles. Political speech generally does not include common insults, sexually suggestive remarks or propositions, or posting pornography. However, the inquiry into what speech contributes to selfgovernance will necessarily be context-specific. For example, a common insult directed at a female political candidate, and tied to the speakcr's views about the election, is political speech. For a discussion of the importance of political speech, see infra Part IV.C. 
leaves the right to engage in political speech too vulnerable. ${ }^{73}$ While workplace harassment laws may seem not to regulate political speech, ${ }^{74}$ creating a categorical workplace-speech exception to the protections of the First Amendment would leave the field open for regulations aimed more directly at speech considered valuable.

\section{Supreme Court Doctrine}

The Supreme Court has not directly addressed whether private employees have a lower level of protection from government regulation of speech wline on the job than does the public in general. However, the Court has addressed workplace speech rights in two areas: the speech rights of private employers in the context of labor relations and the speech rights of public employees. The lessons each area of doctrine holds for workplace speech rights are addressed in turn below. Taken together, the two strands of doctrine demonstrate persuasively that First Amendment protections are not left behind when an employee enters the workplace.

\section{a. Private (Employer) Speech Rights}

In NLRB v. Gissel Packing Co., ${ }^{75}$ the Court recognized that a private einployer's speech may, in certain circumstances, be regulated. The National Labor Relations Act stated that " any views, argument, or opinion' [expressed by an einployer] shall not be 'evidence of an unfair labor practice,' so long as such expression contains 'no threat of reprisal or force or promise of benefit." "76 The Court held that this regulation did not violate the First Amendment rights of employers, but also noted those rights are "firmly established." The Court explained that the National Labor Relations Act merely balanced the free speech rights of the employers against the right of the einployees to associate freely. Further, the Court stated that this balancing must take into account "the economic dependence of the employees on their employers, and the necessary tendency of the former, because of that relationship, to pick up intended implications of the latter that might be more readily dismissed by a more disinterested ear."78 Hence, $m$ the context of labor negotiations, an employer nnay communicate

73. One commentator has argued that "[i]t is difficult to avoid the conclusion that some who would protect the speech of students and faculty but not the speech of workers possess an elitist perspective that simply values the former group of speakers more than the latter." Kingsley R. Browne, Title VII as Censorship: Hostile-Environment Harassment and the First Amendment, 52 Oно ST. L.J. 481, 482 (1991). While Professor Browne perhaps overstates the case, it is important to protect speech rights in the workplace as well as on the college campus.

74. A questionable assumption. The statement "women do not belong im the workplace" is both potentially discriminatory and political.

75. 395 U.S. 575 (1969).

76. Id. at 617 (quoting 29 U.S.C. $\S 158$ (c) (1959)).

77. Id.

78. Id. 
his views to his employees, but he may neither threaten them nor promise benefits in an atteinpt to infringe their associational rights. ${ }^{79}$

Although Gissel restricts an employer's speech rights in the limited context of the employer's anti-union efforts, it does not support a workplace-speech exception to First Amendment protection. First, to the extent that Gissel applies by analogy to non-labor contexts, it seeins to apply only to quid pro quo harassment, in which the threat or promise of a benefit is used to gain sex from an employee. The analogy to hostile environment harassment involving co-workers is quite weak, because often there is not the same power structure between harasser and victim. In other words, a harassing co-worker is not in a position of authority over the victin of harassment, so that concern over employment-related threats or promises is mitigated.

Second, the Court expressly affirmed that the employer's free speech rights exist and "cannot be infringed by a union or the Board." What apparently can place limits on the employer's First Amendment free speech rights are the employee's associational rights in the labor context. To turn this into a categorical exception for all private-sector workplace speech, employer and employee alike, is simply not logically supportable.

\section{b. Public (Employee) Speech Rights}

The Court has held that a state, acting as an employer, may regulate and punish employee speech. However, the public employer cannot ignore First Amendment limitations:

The determination whether a public employer has properly discharged an employee for engaging in speech requires "a balance between the interests of the [employee], as a citizen, in commenting upon matters of public concern and the interests of the State, as an employer, in promoting the efficiency of the public services it performs through its employees." 81

Thus, under the Pickering/Connick standard, when a state employee speaks as a citizen regarding matters of public concern, the state is limited in its ability to discipline based on the speech. Whether speech actually regards a matter of public concern is determined by "the content, form, and context of a given statement." ${ }^{12}$ Speech about political issues clearly regards matters

79. This limitation is somewhat analogous to the more general proposition that extortion is not protected by the First Amendment. See supra note 20 and accompanying text.

80. Gissel, 395 U.S. at 617.

81. Rankin v. McPherson, 483 U.S. 378, 384 (1987) (alteration in original) (quoting Pickering v. Board of Educ., 391 U.S. 563, 568 (1968); citing Connick v. Myers, 461 U.S. 138, 140 (1983)). When speech regards a matter of public concern, the First Amendment interests of the speaker are balanced against the state's interest in maintaining efficiency in its workplaces. However, the "inappropriate or controversial character of a statement is irrelevant to the question [of] whether it deals with a matter of public concern." Id. at 387.

82. Id. at 385 . 
of public concern, while speech that relates only to the speaker's personal interests does not. Put differently, a person is speaking as a citizen when discussing issues of obvious political or social inportance, and is speaking as an employee when issues of office administration or work-related grievances are discussed. ${ }^{83}$ Between such extremes, courts must make " 'imdependent constitutional judgment[s] on the facts of [each] case." "84 While the nature of this test makes it impossible to draw categorical lines demarcating the level of speech protection in the public-sector workplace, it is clear that at least some public workplace speech receives protection. ${ }^{85}$

The public employee speech cases supports the notion that we do not abandon all of our speech rights when we become employees. While government einployees are afforded less protection at work than in general society, they do retain some speech rights. Moreover, as reiterated by the Court in Connick, "the State's interests as an employer in regulating the speech of its employees 'differ significantly from those it possesses in connection with regulation of the speech of the citizenry in general." "\$86 If the government as employer cannot conipletely regulate speech, how much less power should the government have when it is operating not as an employer, but simply as a government? ${ }^{87}$

\section{B. Basic Free Speech Doctrine, and How Hostile Environment Law Violates It}

The preceeding Section establishes that employees in all workplaces receive some level of First Amendment protection from government censorship. Particularly in private workplaces, where the government is acting solely in a governmental capacity, an employee's First Amendment protection renains firmly intact. This Section examines hostile environment law in light of the First Amendment and concludes that, $\mathrm{m}$ its attempt to achieve the goal of workplace equality, hostile environment law violates the basic doctrines of free expression.

83. Actually, the distinction is not as clear as this discussion suggests. The Connick Court split five/four over whether the bulk of the speech for which the employee was fired-a questionnaire distributed to other employees at the district attorney's office-was related to a matter of public concern. Connick, 461 U.S. at 148-49 (finding by majority that, with one exception, the questions on the questionnaire were not related to issues of public concern); id. at 156 (arguing in dissent that Ms. Myers' questionnaire addressed matters touching on the way in which government is or should bo operated and hence involved issues of public concern).

84. Id. at 150 n.10 (quoting Jacobellis v. Ohio, 378 U.S. 184, 190 (1964) (Brennan, J.)).

85. Indeed, the Connick Court stressed that even speech which does not relate to a matter of public concern is not entirely without First Amendment protection. Id. at 147.

86. Id. at 140 (quoting Pickering v. Board of Educ., 391 U.S. 563, 568 (1968)).

87. See generally Post, supra note 57 (examining public forum doctrine and suggesting a reformulation that distinguishes govemance, as in a public forum, from management, as in a nonpublic forum). 


\section{Content Discrimination}

The Supreme Court has held repeatedly that content-based speech regulations violate the First Amendment. ${ }^{88}$ In reality, the Court does allow some forms of regulation based on content; for example, the Court has approved the regulation of obscenity and fighting words. However, these are limited categories carved out by the Court and simply placed beyond the reach of First Amendment protections. ${ }^{89}$ For speech not falling within an unprotected category, however, any content-based regulation must survive the highest level of scrutiny:90 the government "must show that its regulation is necessary to serve a compelling state interest and that it is narrowly drawn to achieve that end." 91

Hostile environment sexual harassment law allows punishment for speech based on content. To establish liability, the plaintiff must slow that a reasonable person (or woman) would find the environment abusive, and that the victim herself perceives the environment as hostile or abusive. ${ }^{92}$ Under Title VII hostile environment law, then, liability for speecl is based on a reasonable recipient's reaction to the speech. Texas $v$. Johnson held that laws that define the legality of speech with reference to the inipact on the hearer constitute content regulation. ${ }^{93}$

Nor does the objective portion of the hostile environment test save the regulations from being content-based. The statute in Johnson proscribed mistreating the flag in a way that the actor " knows will seriously offend one or more persons likely to observe or discover his action." "94 The statute implicitly incorporated an objective standard. If the actor must know he will offend observers, it seems logical to imply that the observers must be reasonable - otherwise, how could the actor be charged with knowledge that his actions were offensive? This component of objectivity did not save

88. See, e.g., R.A.V. v. City of St. Paul, Minn., 112 S. Ct. 2538, 2542 (1992); Texas v. Johnson, 491 U.S. 397, 406 (1989); Cantwell v. Connecticut, 310 U.S. 296, 309-11 (1940).

89. A caveat is necessary here: even within these unprotected categories, regulating speech based on content is constitutionally suspect. See R.A.V., 112 S. Ct. at 2545 (holding that although statute regulated only fighting words, it was content based and therefore violated the First Amendinent). Thus, the First Amendment is not entirely irrelevant to the regulation of unprotected categories of speech.

90. See, e.g., Consolidated Edison Co. v. Public Serv. Comm'n, 447 U.S. 530, 537 (1980) ("As a general matter, 'the First Amendment means that government has no power to restrict expression because of its message, its ideas, its subject matter, or its content," ") (quoting Police Dep't v. Mosley, 408 U.S. 92, 95 (1972)); Erznoznik v. City of Jacksonville, 422 U.S. 205, 210 (1975) ("[T]he Constitution does not permit government to decide which types of otherwise protected speech are sufficiently offensive to require protection for the unwilling histener or viewer.").

91. Widmar v. Vincent, 454 U.S. 263, 270 (1981).

92. See Harris v. Forklift Sys., Inc., 114 S. Ct. 367, 371 (1993).

93. 491 U.S. at 403 n.3, $411-12$ (reasoning in part that the Texas law, as applied to Johnson's political expression, was a content-based restriction on expression because "[w]liether Johnson's [buming] of the flag violated Texas law . . . depended on the likely communicative impact of his expressive conduct"); see also Forsyth County, Ga. v. Nationalist Movement, 112 S. Ct. 2395, 2403 (1992) ("Listeners' reaction to speech is not a content-neutral basis for regulation.").

94. Johnson, 491 U.S. at 411 n.7 (quoting Tex. PeNAl Code ANN. § 42.09(b) (West 1989)). 
the statute in Johnson, and the objective component of hostile environment law does not give it content neutrality.

Although the eradication of sexual discrimination in the workplace inay be a coinpelling state interest, ${ }^{95}$ strict scrutiny is an exceedingly difficult test to meet. The "necessary" and "narrowly tailored" requirements inandate that there be no less speech-restrictive ineans to achieve the compelling state interest. ${ }^{96}$ There is alinost always a less speech-restrictive means for achieving any state interest. For instance, the proscription of quid pro quo harassment fights workplace discrimination without infringing on speech rights. Discrimination cases based on disparate inpact are another example of a means to fight discrimination without limiting speech. ${ }^{97}$ Finally, a more narrowly defined standard of hostile environment liability could suppress less speech while still advancing the goals of Title VII. ${ }^{98}$

\section{Viewpoint Discrimination}

Even inore offensive to the First Amendment than content regulation is viewpoint regulation. The difference may be briefly stated. Content regulation occurs when the government says: "no one may discuss apples at all." Viewpoint regulation occurs when the government says: "no one may advocate eating apples." The former regulation is suspect because it limits speech based on subject matter, and hence strict scrutiny is applied. The latter regulation is even worse than content regulation: under such a law, people would be free to argue against eating apples, but the opposing viewpoint would be silenced. While this example is trivial, the notion that the government should not be able to give a relative advantage to certain viewpoints is not. ${ }^{99}$ Hostile environment sexual harassment law is viewpoint

95. See, e.g., Johnson v. County of Los Angeles Fire Dep't, 865 F. Supp. 1430, 1439 (C.D. Cal. 1994) ("There is no doubt that the prevention of sexual harassment is a compelling governmental interest.").

96. See, e.g., Boos v. Barry, 485 U.S. 312,329 (1988) (holding that even if preserving the dignity of foreign diplomats were compelling, a statute prohibiting signs which brought foreign governments into public disrepute was not narrowly tailored).

97. Disparate impact claims "involve employment praetiees that are facially neutral in their treatment of different groups, but which in fact have adverse cffects which disproportionately fall on one group and cannot be justified by business necessity." Jenson v. Evcleth Taconite Co., 824 F. Supp. 847, 861 (D. Minn. 1993).

98. One might think that, taking as a given that the eradication of a sexually diseriminatory work environment is a compelling government interest, a regulation could reach all workplace speech with a disparate impact on women and still be narrowly tailored. However, each instance of speeeh with a disparate impact does not in and of itself constitute discrimination. In order to justify regulation of all speech that has a disparate impact on women in the workplace, the government interest would have to be broadened to encompass speech that does not rise to the level of hostile environment harassment; this broader interest is not compelling. Thus, it seems clear that hostile environment law violates either the compelling interest or the narrowly tailored requirement, depending upon how broadly the government interest is defined.

99. See Geoffrey R. Stone, Content Regulation and the First Amendment, 25 WM. \& MARY L. REv. 189, 197-200 (1983) (discussing the distorting effect of viewpoint regulations on public debate). 
discriminatory. Statements hostile to women in the workplace could lead to liability. Statements supportive of women would not. To take an example from Harris, the statements "women are as competent as men" and "we welcome a woman as the rental manager" would be quite welcome at the worksite (assuming they are meant sincerely). The statements quoted by the Court were quite similar: "[y]ou're a woman, what do you know," and "[w]e need a man as the rental manager." The only difference between the cominents actually made in Harris and my hypothetical cominents are the viewpoints they advance. Under hostile environment law, statements advocating equality would not result in liability. However, statements evincing a belief in mequality of the sexes could result in liability. This is a clear example of viewpoint discrimination.

The practical result of finding a regulation viewpoint discriminatory is not entirely clear. For example, in R.A.V. v. City of St. Paul, Minn., ${ }^{101}$ Justice Scalia, writing for the Court, acknowledged that "[i]n its practical operation ... the ordinance goes even beyond inere content discrimination, to actual viewpomt discrimination." 102 The opimion continued, however, to apply strict scrutiny, just as it would have if the ordinance had suffered only from content discrimination. ${ }^{103}$ Nonetheless, the Court considers viewpoint discrimination to be a worse form of infringement on free speech, ${ }^{104}$ and one Justice has asserted im concurrence that a regulation that constitutes viewpoint discrimination is even less likely to withstand judicial scrutiny than a regulation that only discriminates based on content. ${ }^{105}$

\section{Prior Restraint}

The term "prior restramt" refers to the method employed by the government in restricting speech. ${ }^{106}$ "[R]estrictions which could be validly

Professor Stone also notes that viewpoint-based regulations undermine the self-fulfillment rationale of the First Amendment. Id. at 198 n.10.

100. See, e.g., Harris v. Forklift Sys., Inc., 114 S. Ct. 367, 369 (1993).

101. 112 S. Ct. 2538 (1992).

102. Id. at 2547 .

103. Id. at $2549-50$.

104. See, e.g., First Nat'l Bank of Boston v. Bellotti, 435 U.S. 765, 785-86 (1978) ("Especially where ... the legislature's suppression of speech suggests an attempt to give one side of a debatable public question an advantage in expressing its views to the people, the First Amendment is plainly offended.") (footnote omitted); R.A.V., 112 S. Ct. at 2569 (Stevens, J, concurring) ("[I]n general, viewpoint-based restrictions on expression require greater scrutiny than subject-matter based restrictions."); see also Perry Educ. Ass'n v. Perry Local Educators' Ass'n, 460 U.S. 37, 62 (1983) (Brennan, J., dissenting) ("Viewpoint discrimination is censorship in its purest form . . ..").

105. R.A.V., $112 \mathrm{~S}$. Ct. at $2569 \mathrm{n} .7$ (Stevens, J. concurring) ("Although the Court has sometimes suggested that subject-matter based and viewpoint-based regulations are equally problematic . . our decisions belie such claims.") (citing Consolidated Edison Co. v. Public Serv. Comm'n, 447 U.S. 530, 537 (1980)).

106. See Laurence H. Tribe, American Constitumonal Law $\S 12-34$, at 1040 (2d ed. 1988) ("[T]he [prior restraint] doctrine imposes a special bar on attempts to suppress speech prior to publication, a bar that is distinct from the scope of constitutional protection accorded the material after publication."). 
imposed when enforced by subsequent punishment are, nevertheless, forbidden if attempted by prior restraint." 107 In other words, prior restraints are categorically suspect under First Amendment doctrine, even if the targeted speech could be punished after publication.

An ijunction is generally considered to be a form of prior restraint, ${ }^{108}$ at least in part due to the collateral bar rule, which mandates that an injunction, even if unconstitutional, be obeyed until successfully appealed. ${ }^{109}$ The danger is clear: an mjunction reaching protected speech ${ }^{110}$ inust be obeyed until it is set aside. Moreover, the First Amendment cannot operate as a defense to a contempt charge if the injunction is violated. An injunction thus stifles protected speech far more completely than subsequent punishment, to. which the freedom of speech guarantee does provide a defense.

Hostile environment sexual harassment regulations allow the trial court, through an imjunction, to direct an einployer to adopt certain guidehines and procedures aimed at getting rid of the abusive work environment. Robinson v. Jacksonville Shipyards, Inc., ${ }^{11}$ provides an example. The district court issued an mjunction ordering an employer to adopt a courtcrafted sexual harassment policy. ${ }^{112}$ The policy prohibited the making of sexually-oriented gestures or telling of such jokes in the presence of any employee who has indicated that such "conduct" is unwelcome; ${ }^{113}$ the displaying of any kind of pictures, graffiti, objects, or reading inaterial that is sexually suggestive; ${ }^{114}$ and the reading of such material at the workplace. ${ }^{115}$ This injunction acts as a prior restraint. Its broadness, covering activity which is arguably protected by the First Amendment, makes it unlikely to survive the Court's stringent exammation of prior restraints. ${ }^{116}$

107. Thomas I. Emerson, The Doctrine of Prior Restraint, 20 LAw \& ContemP. Probs. 648, 648 (1955).

108. The case establishing the suspect nature of injunctions based upon their operation as a prior restraint was Near v. Miunesota, 283 U.S. 697, 720, 722-23 (1931) (holding that while newspapers may have no right to publish certain material, an injunction against the publication of such matcrial was unconstitutional because the primary aim of the First Amendment was to prevent pre-publication restraints).

109. See Walker v. City of Birmingham, 388 U.S. 307, 320-21 (1967) (upholding the collateral bar rule against a First Amendment challenge).

110. Prior restraints are constitutionally suspect even when the speech is unprotected. Howcver, in the case of hostile environment law, some enjoined speech is very likely to be protected. See, e.g., Near, 283 U.S. at 719 (1931).

111. 760 F. Supp. 1486 (M.D. Fla. 1991). The sexual harassment policy the court ordercd be adopted is set out at pp. $1541-46$ of its opinion.

112. Id. at 1541 .

113. Id. at 1542.

114. Id. Sexually suggestive is defined as something which "depicts a person of either sex who is not fully clothed" or whose clothes "are not suited to or ordinarily accepted for the accomplishment of routine work im and around the [worksite] and who is posed for the obvious purpose of displaying or drawing attention to private portions of his or her body." Id.

115. Id.

116. See Johnson v. County of Los Angeles Fire Dep't, 865 F. Supp. 1430 (C.D. Cal. 1994). The Court has becn more likely to uphold prior restraints that prohibit a very narrow range of speech, 
An employee is not directly subject to an injunction imposed on an employer under Title VII, and so could presumably bring a collateral attack on the court-imposed policy. However, it is possible that an employer (for example, the individual owner of a business) who desired to engage in speech banned under an injunction such as the one in Robinson would be himited to a direct appeal. ${ }^{117}$ This aspect of hostile environment law is suspect under the prior restraint doctrine.

\section{Vagueness and Overbreadth}

The doctrines of vagueness and overbreadth are often discussed together, as if there were little or no distinction between the two. Although the concepts can merge, they are distinct doctrines. A statute is unconstitutionally vague if the conduct it forbids is not clearly enough defined, so that people of "common intelligence must necessarily guess at its ineaning and differ as to its application."118 A statute is unconstitutionally overbroad if, in addition to reaching activities that inay be constitutionally forbidden, it also proscribes a substantial anount of speech or conduct that is protected by the First Amendment. ${ }^{119}$

The regulation of sexual harassment based on an offensive or hostile environment may be both too vague and too overbroad to withstand scrutiny. ${ }^{120}$ First, the standard of liability is vague. As discussed above, district and circuit courts have applied the standard differently in several important respects; how inuch less clear must the standard be to einployers, einployees, and juries? Justice Scalia comments on the vagueness of the words "abusive" and "hostile" in his concurring opmion in Harris: "As a practical matter, today's holding lets virtually unguided juries decide whether sexrelated conduct engaged in (or permitted by) an employer is egregious enough to warrant an award of damages."121 While vagueness raises due

particularly if that speech has already been judged unprotected. See, e.g., National Soc'y of Professional Eng'rs v. United States, 435 U.S. 679, 697 (1978).

117. The Robinson court asserted that "[t]he first amendment [sic] guarantee of freedom of speech does not impede the remedy of injunctive relief." $760 \mathrm{~F}$. Supp. at 1534 . For support of this conclusory statement, the court cited other Title VII cases involving racial and sexual harassment, but iguored Supreme Court doctrine.

118. Connally v. General Constr. Co., 269 U.S. 385, 391 (1926); accord UWM Post, Inc. v. Board of Regents, 774 F. Supp. 1163, 1178 (E.D. Wis. 1991) ("A statute is unconstitutionally vague when 'men of common intelligence mnst necessarily guess at its meaning.' ") (quoting Broadrick v. Oklahoma, 413 U.S. 601, 607 (1973)).

119. Broadrick, 413 U.S. at $612-13$. Note that vagueness doctrine is based on notions of due process, and so is employed in a variety of doctrinal areas, while overbreadth is a principle of First Amendment doctrine. Id. at 611 .

120. See J.M. Balkin, Some Realism About Pluralism: Legal Realist Approaches to the First Amendment, 1990 DukE LJ. 375, 425 ("If a statute involving loitering or breach of the peace used language of such generality [as the EEOC regulation], 1 suspect that most left-libertarians immediately would pronounce it overbroad and vague.").

121. Harris v. Forklift Sys., Inc., I14 S. Ct. 367, 372 (1993) (Sealia, J., concurring). 
process concerns in many circumstances, it is of particular concern when a regulation suppresses speech.

In addition to being vague, the standard inay be overbroad. The EEOC regulations and case law developed froin the regulations impose liability for pure speech, as well as for the posting of pornography, which, if not obscene, is protected by the First Amendment. ${ }^{122}$ In addition, the imdirect inechanisin by which hostile environment law restricts employee speech contributes to its overbreadth. For co-worker harassment, the employer must take adequate steps to remedy harassment about which he or she should reasonably be aware, or the employer will be subject to liability. ${ }^{123}$ One commentator has noted that this imdirect form of speech restriction is perhaps an even greater danger to free speech than direct regulation:

The incentive for employers to suppress speech is particularly great because the employer is hable for its employees' offensive speech ... but derives no benefit from it. In this respect, harassment law differs from, say, libel law, im which hability is imposed on the speaker itself (the newspaper). The newspaper may be chilled by the possibility of a libel judgment if a story about a private figure turns out to be false, but the newspaper's imterest in reporting the story counteracts the chilling effect to some extent. There is no similar force working agaimst the chilling effect of harassment law. A prudent employer who is faced with even a small possibility of liability would quite likely demand that its employees avoid even arguably harassing speech. ${ }^{124}$

In other words, because an employer cannot determine prospectively when isolated incidents will rise to the level of actionable harassment - the line drawn by Meritor - the employer must regulate the isolated incidents themselves. Courts also have hinted at this dynamic:

We realize that it is unrealistic to hold an employer accountable for every isolated incident of sexism, however, we do not consider it an unfair burden on an employer of both genders to take measures to prevent an atmosphere of sexisin to pervade [sic] the workplace. "[W]hile Title VII does not require that an employer fire all 'Archie Bunkers' in its employ, the law does require that an employer take prompt action to prevent such bigots from expressing their opinion in a way that abuses or offends their co-workers. By informing people that the expression of racist or sexist attitudes in public is unac-

122. See American Booksellers Ass'n v. Hudnut, 771 F.2d 323, 332 (7th Cir. 1985) (striking down a pornography ordinance on the ground that it constituted viewpoint discrimination), aff'd. 475 U.S. 1001 (1986).

123. 29 C.F.R. $\$ 1604.11$ (d) (1994). Note that if the harassment is carried out by someone acting in a supervisory or agency capacity, the employer will be liable regardless of whether he or she did or should have known about the liarassment. 29 C.F.R. $\$ 1604.11$ (c) (1994).

124. Volokh, supra note 70 , at 1810-11 (footnotes omitted). 
ceptable, people may eventually learn that such views are undesirable in private, as well. Thus, Title VII may advance the goal of eliminating prejudices and biases in our society."125

Thus, hostile environment harassinent law, which supposedly imposes liability only when speech or conduct rises to the requisite level of severity and pervasiveness, is transformed into a regulation that requires an employer to prevent "bigots from expressing their opinions in a way that ... offends." To avoid the possibility of liability, each offensive remark inust be eliminated froin the workplace. Even in federal circuits where the courts are less explicit, the dynamic remains the same. An einployer inust still atteinpt to eliminate all offensive speech and conduct froin the workplace or worry that the sum total of sucli expression might rise to the level of hostile environment harassinent. ${ }^{126}$

As shown, hostile environment sexual harassinent law arguably is both vague and overbroad. Not only is the standard unclear in terms of its application to specific factual situations, but einployers are, as a practical inatter, encouraged to ban even isolated incidents of offensive speech and conduct. Any standard created to replace the present one should be sensitive to these concerns. ${ }^{127}$

$$
* * * *
$$

The foregoing has argued that hostile environment sexual liarassinent law violates general free speech primciples developed by the Supreme Court. The next Part considers whether any existing exception to those principles saves current hostile environment law.

\section{III}

\section{Can Hostile Environment Sexual Harassment Law Be SAVED BY ANY EXISTING EXCEPTION?}

The Court has, over the years, carved out limited exceptions to the absolute rule that no law shall be made abridging the freedoin of speech. If hostile environment liarassment law fits into one of the existing exceptions, then it will survive First Amendment challenges. Ultinately, I conclude that sexual harassinent law does not fit wholesale into any existing exception. However, an analysis of current doctrine will aid in this Comment's goals: to suggest a sexual harassment standard that infringes upon the least speech possible while promoting the goal of equality, and to recommend an

125. Andrews v. City of Philadelphia, 895 F.2d 1469, 1486 (3d Cir. 1990) (emphasis added) (quoting Davis v. Monsanto Chem. Co., 858 F.2d 345, 350 (6th Cir. 1988), cert. denied, 490 U.S. 1110 (1989)).

126. This is, generally speaking, the type of evil that vagueness doctrine is supposed to prevent. A vague statute affecting specch is offensive to the First Amendment because it "chills" speech beyond that which the state seeks to regulate.

127. But see Balkin, supra note 120 , at 425 (arguing that the overbreadth and vagueness doctrines are "ill-adapted to the problems of the present era" and that vagueness and overbreadth analysis must be applied differently to sexual harassment law). 
adaption of First Amendment doctrine to allow room for the regulation of workplace harassment.

\section{A. Obscenity, Defamation, and Fighting Words}

Obscenity, defamation, and fighting words are exceptions to First Amendment protection that the Court has created based on the content of the speech. At one time or another, the Court has declared each of these content-based categories to be unprotected by the First Amendment.

\section{Obscenity}

Obscenity is currently defined for First Amendment purposes under the three-part test laid down in Miller v. California. ${ }^{128}$ Material is obscene if: (1) "the average person, applying contenuporaneous community standards would find that the work, taken as a whole, appeals to the prurient interest"; (2) "the work depicts or describes, in a patently offensive way, sexual conduct specifically defined by the applicable state law"; and (3) "the work, taken as a whole, lacks serious literary, artistic, political, or scientific value."129 To avoid problems of vagueness and overbreadth, the Court gave specific exaniples of material that could be banned, including "[p]atently offensive representations or descriptions of ultimate sexual acts, normal or perverted, actual or simulated" and of "niasturbation, excretory functions, and lewd exhibition of the genitals."130

As the Court's definition and examples make clear, only what are generally categorized as graphic, "hard-core" descriptions or depictions of sexual activity or nudity will be deemed sufficiently obscene to lose First Amendment protection. While some workplace speech (including pornographic pinups) nuay meet this standard, much of it will not. For example, a picture of a completely nude woinan who does not have her legs spread, but who is nonetheless posed in a sexual nianner, would very likely not be "obscene" so as to place it beyond the reach of the First Amendnient. Thus, inuch of the harassing conduct prohibited by hostile environment law cannot be justified through reliance on the obscenity exception.

\section{Defamation}

Statenients that defame groups were declared unprotected by the First Amendment in Beauharnais v. Illinois. ${ }^{131}$ In upholding the group libel statute, the Court essentially allowed states to define libel for theniselves. ${ }^{132}$

128. 413 U.S. 15 (1973).

129. Id. at 24 (internal quotations omitted).

130. Id. at 25 .

131. 343 U.S. 250,258 (1952).

132. The Court explained:

The precise question before us, then, is whether the protection of "liberty" in the Due Process Clause of the Fourteenth Amendment prevents a State from punishing such libels-as criminal libel has becn defined, limited and constitutionally recognized time out of mind- 
This deference would seem to allow regulation of some speech aimed at women in the workplace, at least to the extent that we consider such speech defamatory. ${ }^{133}$

But since Beauharnais, the Court has himited the freedom of the states to define and punish libel. In New York Times Co. v. Sullivan, the Court ruled that the First Amendment prohibits a public official from recovering damages for false, defamatory statements relating to his official conduct unless "actual inalice"- defined as knowledge or reckless disregard with respect to the falsity of the statements-can be shown. ${ }^{134}$ This standard has been extended to cover defamation of public figures, ${ }^{135}$ although more lenient First Amendment standards apply to defamation actions brought by private figures. ${ }^{136}$ In light of the limitations the Court established in New York Times and its progeny, and to the extent that Beauharnais was based on the states' freedom to define libel for thenselves, Beauharnais may no longer be viable. Hence, the group hibel doctrine is a weak basis on which to rest the constitutionality of hostile environment law.

Furthermore, the Court in Milkovich v. Lorain Journal Co. held that statements of opinion are not hibelous unless they can " "reasonably [be] interpreted as stating actual facts' about an individual."137 While Milkovich involved statements that had been published or broadcast in the media, the reasoning applies outside that context. In establishing that opinions that do not reasonably imply knowledge of facts about an individual are constitutionally protected, the Court balanced the First Amendment's "vital guarantee of free and uninhibited discussion of public issues" against society's "pervasive and strong interest in preventing and redressing attacks upon reputation."138 These interests are implicated to at least sonie extent regardless of the context of an allegedly libelous statement.

\footnotetext{
directed at designated collectivities and flagrantly disseminated. . . . [I]f an utterance directed at an individual may be the object of criminal sanctions, we cannot deny to a State power to punish the same utterance directed at a defined group, unless we can say that this is a wilful and purposeless restriction unrelated to the peace and well-being of the State.
} Id.

133. A statement is defamatory if it harms the subject's reputation in the sense that it diminishes the respect or confidence in which she is held, or excites derogatory feelings or opinions against her. See Prosser and Keeton on the Law of Torts 773-73 (W. Page Keeton et al. eds., 5th ed. 1984).

134. 376 U.S. $254,279-80$ (1964). Note that slander is the term specific to spoken defamation and libel the term for written defamation. However, because no distinction betwecn the two types of defamation is generally made in First Amendment analysis, this Comment uses the terms interchangeably.

135. Curtis Publishing Co. v. Butts, 388 U.S. 130 (1967), overruled in part by Gertz v. Robert Welch, Inc., 418 U.S. 323 (1974).

136. Gertz v. Robert Welch, Inc., 418 U.S. 323 (1974). The Court declined to apply the New York Times standard to libel actions by private figures but held that states cannot impose liability without a showing of fault. Id. at 343,347 .

137. 497 U.S. 1, 20 (1990) (alteration in original) (quoting Hustler Magazine, Inc. v. Falwell, 485 U.S. 46, 50 (1988); citing Grecnbelt Coop. Publishing Ass'n v. Bresler, 398 U.S. 6 (1970); Letter Carriers v. Austin, 418 U.S. 264 (1974)).

138. Id. at 22 (quoting Rosenblatt v. Baer, 383 U.S. 75, 86 (1966)). 
The limitation of libel law to statements of fact and statements of opinion that are reasonably interpreted as stating facts would allow regulation of very little of the workplace speecl that contributes to a hostile environment. Stateinents about groups will virtually always be mere opmions. And while there is no outright opmion privilege after Milkovich, First Amendment protection remains for all opmions which do not reasonably state facts. For exainple, statements such as "women are only good for one thing" cannot be reasonably mterpreted to state actual facts about an individual or a group of individuals. One of the Court's concerns in Milkovich, in fact, was to protect such "rhetorical hyperbole."139

Individual libel doctrine, however, will still cover some workplace statements. For example, a false statement that a female professor had sex with her department head in order to gaim influence and advantage ${ }^{140}$ would be libelous. However, most harassing statements would not qualify as libel, because they neither state nor imply facts. The statement that a particular woinan is imcapable of performing her job well would be protected as an opinion. Furthermore, expressive behavior such as the posting of pornographic posters is difficult to classify as libel. ${ }^{141}$

In summary, whether because statements about groups will virtually always be protected opimions or because the states' freedom to define libel - and lience the basis of Beauharnais - has been undermined, group libel is no longer a viable doctrine. Moreover, only rarely will statements that contribute to a hostile environment constitute defamation of an individual. Hence, the defamation exception to the First Amendment cannot operate to save hostile environment sexual harassment law because much harassing speecli would not be covered.

\section{Fighting Words}

The fighting words doctrine originated in Chaplinsky v. New Hampshire. ${ }^{142}$ The Court held that the "certain well-defined and narrowly linited classes of speech" that traditionally have been placed outside of constitutional protection included 'insulting or 'fighting words'-those which by their very utterance inflict injury or tend to imcite an immediate breach of the peace."143 The Court reasoned that "such utterances are no essential part of any exposition of ideas," and that any slight value they may have as a step to truth was "outweighed by the social interest in order and morality."144

139. Id. at 17 (quoting Bresler, 398 U.S. at 13-14).

140. See Jew v. University of Iowa, 749 F. Supp. 946,958 (S.D. Iowa 1990).

141. But see generally Catharine A. MacKinnon, Pornography as Defamation and Discrimination, 71 B.U. L. REv. 793 (1991) (discussing the similarities, and differences, of pornography and traditional forms of group hibel).

142. 315 U.S. 568 (1942).

143. Id. at $571-72$.

144. Id. at 572. 
Under the Chaplinsky rationale, sexually harassing speech could be banned if its very utterance inflicts injury on the victim of the harassment. However, the Court has limited the fighting words doctrine since Chaplinsky. ${ }^{145}$ Most significantly, in Cohen v. California, ${ }^{146}$ the Court held that the First Amendment does not allow words to be punished smiply because they are offensive.

The defendant in Cohen was prosecuted for violating a statute prohibiting the intentional disturbance of the peace through offensive conduct. $\mathrm{He}$ had worn a jacket bearing the legend "Fuck the Draft" im a courthouse corridor. ${ }^{147}$ In concluding that this was not a fighting words case, the Court omitted mention of the "by their very utterance inflict injury" coinponent of the doctrine, and described the doctrine in terms which seemed to himit it to instances in which a breach of the peace was threatened:

This Court has also held that the States are free to ban the simple use, without a demonstration of additional justifying circumstances, of so-called "fighting words," those personally abusive epithets which, when addressed to the ordinary citizen, are, as a matter of common knowledge, inherently likely to provoke violent reaction. ${ }^{148}$

The Court has repeated the "inflict injury" language since the narrowing of the fighting words doctrine in Cohen. ${ }^{149}$ The Court, however, has not applied the "inflict mjury" coinponent to uphold any statutes. Whether or not the "inflict imjury" aspect of the fighting words doctrine is still viable, it is clear that the injury inflicted may not be simple offense. ${ }^{150}$

Despite the fact that soine harassing speech could conceivably fall into the ambit of the fighting words doctrine, ${ }^{151}$ it is nonetheless inadequate for saving hostile environment sexual harassment law from First Amendment challenges. First, as noted by Professor Strauss, Title VII harassment law does not require that the words be directed at an individual. ${ }^{152}$ To qualify

145. TRIBE, supra note $106, \S 12-10$, at $850-53, \S 12-18$, at $929-30 \mathrm{n.9}$ (describing the narrow construction given the fighting words doctrine by the Court and by commentators).

146. 403 U.S. 15 (1971).

147. Id. at 16 .

148. Id. at 20 .

149. See, e.g., Hustler Magazine, Inc. v. Falwell, 485 U.S. 46, 56 (1988) (quoting Chaplinsky v. New Hampshire, 315 U.S. 568, 571-72 (1942)); Houston v. Hill, 482 U.S. 451, 461-62 (1987) (quoting Lewis v. City of New Orleans, 415 U.S. 130, 133 (1974)).

150. See Hustler Magazine, Inc., 485 U.S. at 56 (" "It is firmly settled that . . the pubhic expression of ideas may not be prohibited merely because the ideas are themselves offensive to some of their hearers." ') (alteration in original) (quoting Street v. New York, 394 U.S. 576, 592 (1969)); Cohen, 403 U.S. at 25-26 (concluding that speech may not be censored based on offensiveness because offensive words carry an emotive message and may convey ideas, and because, given that "one man's vulgarity is another's lyric," there is no principled way in which to define offensive speech); see also TRIBE, supra note 106, § 12-8, at 838-41 (discussing the "inflict injury" branch of Chaplinsky).

151. See Cohen, 403 U.S. at 20 (describing fighting words generally as "personally abusive epithets").

152. Strauss, supra note 8 , at 18 . 
as "fighting words," however, the abusive language must be directed to an mdividual. ${ }^{153}$ Hostile environment claims have been based on undirected speech $^{154}$ and on pictures posted in the workplace, which are generally not directed at any individual. ${ }^{15}$ This speech cannot be regulated under the fighting words exception, because it is undirected. ${ }^{156}$

The fighting words doctrine is further ill-suited as a rationale for upholding sexual harassment law because inuch of the harassing speech cannot be described as personal epithets. Hostile environment harassment claims have been based on ruinors that a feinale college professor used sex to gain favor and influence with the department head, ${ }^{157}$ statements to the effect that women do not make good police officers (in coinbination with other harassing speech and behavior), ${ }^{158}$ and unsolicited requests for sex by supervisors. ${ }^{159}$ One court hinted that gender-based job titles might have supported a Title VII harassment claim had the employer not taken "reasonable steps to eliminate the discriminatory features of its job titles." 160 None of these types of harassing speech can be classified as fighting words because, while offensive, they do not provoke violent reactions. In this sense, hostile environment law is overinclusive as measured by the fighting words doctrine, proscribing inore speech than the doctrine would allow.

Conversely, some "fighting words" at the workplace are not reached by hostile environment harassment law. Title VII and the EEOC regulations are not designed to reach all workplace fighting words, only those that create a hostile environment for women (or another protected group). Thus, hostile environment law constitutes a content-based distinction among fighting words, a distinction held unconstitutional in $R . A . V .{ }^{161}$ In this

153. See Cohen, 403 U.S. at 20 (noting that because the words on Cohen's jacket were not "directed to the person of the hearer," no individual present could "reasonably have regarded the words on [Cohen's] jacket as a direct personal insult").

154. E.g., Andrews v. City of Philadelphia, 895 F.2d 1469, 1472 (3d Cir. 1990) (recognizing plaintiffs' claim that women in the police department were regularly referred to in an offensive and obscene manner, both in statements directed to women and iu convcrsations among the male officers). Another example of non-directed speech that might contribute to a hostile environment is the use of gender-based job titles. See, e.g., Tunis v. Coming Glass Works, 747 F. Supp. 951, 955 (S.D.N.Y. 1990) (recognizing that gender-based job titles can be discriminatory), aff' $d$ without op., 930 F.2d 910 (2d Cir. 1991).

155. Pictures are directed at an employee if they are left at her workstation or handed to her. For example, in Robinson v. Jacksonville Shipyards, lnc., 760 F. Supp. 1486 (M.D. Fla. 1991), a picture of a nude woman with legs spread and knecs brought up to her chest, so that her breasts and genitals were exposed, was left on the tool box where plaintiff stored her tools. Several men laughed at the plaintiff when she discovered the picture and appeared upset by it. Id. at 1497.

156. For an argument that only directed speech should be regulable as harassment, sce Volokh, supra note 70.

157. Jew v. University of Iowa, 749 F. Supp 946, 958 (S.D. Iowa 1990).

158. Amold v. City of Seminole, Okla., 614 F. Supp. 853, 858, 863 (E.D. Okla. 1985).

159. Bundy v. Jackson, 641 F.2d 934, 940 (D.C. Cir. 1981).

160. Tunis v. Corning Glass Works, 747 F. Supp. 951,959 (S.D.N.Y. 1990), aff'd without op., 930 F.2d 910 (2d Cir. 1991).

161. R.A.V. v. City of St. Paul, Minn., 112 S. Ct. 2538, 2545 (1992). 
sense, hostile environment law is underinclusive when measured by the fighting words doctrine, regulating only certain workplace fighting words.

The conclusion that Title VII hostile environment sexual harassment regulation cannot be justified under the fighting words doctrine is supported by UWM Post v. Board of Regents. ${ }^{162}$ This case involved a university speech rule that was similar in its wording to the Title VII hostile environment standard. The court noted that the similarity "would not make the [university speech r]ule constitutional. Since Title VII is only a statute, it cannot supersede the requirements of the First Amendinent."163 The court added that "freedom of speech is almost absolute in our land and the only restriction the fighting words doctrine can abide is that based on the fear of violent reaction."164 Since the rule was not himited to words which tended to mcite a breach of the peace, the fighting words doctrine could not justify the rule. ${ }^{165}$

\section{B. Time, Place, and Manner}

Reasonable restrictions on the time, place, or manner of speech do not violate the First Amendment. ${ }^{166}$ For example, a city may constitutionally regulate sound amplification at a public bandshell by requiring that its own amplification equipinent and sound technicians be used for all concerts at the bandshell. ${ }^{167}$ However, sexual harassment regulations cannot be classified as inere restrictions on the time, place, or manner of speech. ${ }^{168}$ The Supreme Court has stressed that time, place, and manner restrictions must: (1) be justified without reference to content; (2) be narrowly tailored to serve a significant government interest; and (3) leave open ample alternatives for communication. ${ }^{169}$

Sexual harassinent law arguably satisfies the third requirement of permissible time, place, and manner regulations. Because the law affects only workplace speech, workers are free to express their ideas without fear of sanction elsewhere. One commentator has argued that ample alternatives do not exist for workers because of the large proportion of time that they

162. 774 F. Supp. 1163 (E.D. Wis. 1991).

163. Id. at 1177 .

164. Id. at 1181 .

165. Id. at 1172-73.

166. Ward v. Rock Against Racism, 491 U.S. 781 (1989).

167. Id. at 787,803 .

168. In addressing the constitutionality of hostile environment law, the Robinson court said, "The regulation of discriminatory speech in the workplace constitutes nothing more than a time, place, and manner regulation of speech." Robinson v. Jacksonville Shipyards, Inc., 760 F. Supp. 1486, 1535 (M.D. Fla. 1991) (citing Strauss, supra note 8, at 46 ("[B]anning sexist speech in the workplace does not censor such speech everywhere and for all time.")). Professor Strauss did not explicitly argue that hostile environment sexual harassment law can be justified as a time, place, and manner restriction. Moreover, as will be shown in this Seetion, the Robinson court ignored basic doctrine in reaching this conclusion.

169. Ward, 491 U.S. at 791 (quoting Clark v. Community for Creative Non-Violence, 468 U.S. 288, 293 (1984)). 
spend at the workplace. ${ }^{170}$ As a policy matter, Professor Browne is right to be concerned about the amount of time workers spend at the workplace, and the extent to which they actually do communicate outside the jobsite. However, the Court's decisions in this area do not support his analysis. Quite modest alternative channels have been sufficient undcr the Court's time, place, and manner analysis. ${ }^{171}$ Employees are not barred from communicating their ideas outside of the workplace, and therefore do not lack alternative channels.

Sexual harassinent hostile environment law probably fails the second requirement of time, place, and manner regulations, that they be narrowly tailored to serve a significant government interest. Eradicating sexual discrimination in the workplace is undoubtedly a significant government interest, but the law is not narrowly tailored. As discussed above, hostile environment law suffers from problems of vagueness and overbreadth. ${ }^{172}$ The goal of ensuring nondiscriminatory workplaces can be advanced through regulations that are less speech restrictive than the regulations currently in force. ${ }^{173}$ On the other hand, it is not required that time, place, and manner regulations infringe upon the least speech possible. The requirement is that the Government "not regulate expression in such a manner that a substantial portion of the burden on speech does not serve to advance its goals." 174 Thus, while there is a plausible argument that Title VII sexual harassment regulations are substantially broader than necessary, and hcnce fail the narrowly tailored requirement for time, place, and manner regulations, the resolution of this issue is uncertain.

The most vulnerable aspect of sexual harassment law under time, place, and manner analysis is its lack of content-neutrality. Admittedly, the Court has applied a slightly more lemient content-neutrality standard to time, place, and manner regulations where sexually explicit materials are involved. ${ }^{175}$ However, this lemency is based on the secondary effects of the presence of establishments that deal in adult materials, rather than on the materials' content. ${ }^{176}$ Such "secondary effects" do not imclude the reaction

170. Browne, supra note 73 , at 521 .

171. See, e.g., Renton v. Playtime Theatres, Inc., 475 U.S. 41, 53-54 (1986) (upholding zoning ordinance although very few, if any, reasonable alternative sites would be left for adult theaters under the ordinance); Clark v. Community for Creative Non-Violence, 468 U.S. 288 (1984) (sustaining the proscription against camping in Lafayette Park or the Mall in Washington, D.C. as a permissible regulation of time, place, and manner, over the dissent's argument that slceping in the park would be the most effective means for the homeless protesters to communicate their message).

172. See supra notes 120-127 and accompanying text.

173. An attempt to design a more narrowly tailored standard is set forth infra Part VI.

174. Ward, 491 U.S. at 799.

175. Young v. American Mini Theaters, 427 U.S. 50, $69-71$ (1976). In Young the Court was explicit in allowing the tinse, place, and manner regulation, an anti-skid-row zoning ordinance, to be based on the content of sexually explicit films.

176. Renton, 475 U.S. at 47-50. In Renton, the Court reasoned that it was the "secondary effects" of adult theaters (e.g., the crowd and activities they attract), rather than the content of the films shown, 
of a listener or viewer. ${ }^{177}$ Therefore, under current doctrine, the Court's more lenient standard will not apply in the case of sexual harassment based on a liostile environment, which is expressly determined by the reaction of both the victim and a reasonable person. ${ }^{178}$ Title VII regulation of hostile environment sexual harassment thus cannot be justified as "nothing more than a time, place and nianner regulation of speech."

\section{Harassing Speech as Discriminatory Conduct}

If speech itself constitutes a crime, such as a criminal threat or blackmail, it is not protected speech. ${ }^{179}$ Speech that constitutes hostile environment harassment may not be truly speech, but discriminatory conduct. ${ }^{180}$ Professor Strauss has urged that a distinction be drawn between speech that advocates discrimination, which would be protected, and speech that "discriminates by its very utterance."181 Professor Strauss' analysis has appeal, but it seems dismgenuous to distinguish speech that advocates discrimination from speech that discriminates in the hostile environment arena. Would the statement, "Women don't belong in the workplace," be deemed only to advocate discrimination? Or, if sufficiently severe and pervasive speech were present, could it become discrimination itself?

Justice Scalia used an analysis similar to that of Professor Strauss and the Robinson court in labeling Title VII constitutional in R.A.V.:

[S] ince words can in some circumstances violate laws directed not against speech but against conduct (a law against treason, for example, is violated by telling the enemy the nation's defense secrets), a particular content-based subcategory of a proscribable class of speech can be swept up imcidentally within the reach of a statute directed at conduct rather than speech. Thus, for exainple, sexually derogatory "fighting words," among other words, may produce a violation of Title VII's general prohibition against sexual discrimination in employment practices. ${ }^{182}$

This dictum, and the arguments niade by the Robinson court and Professor Strauss, seems to have force only as apphed to quid pro quo harassment, which is the form of harassment analogous to treason, or to a crim-

that the regulation was based on. Therefore, the ordinance was a content-neutral time, place, and manner regulation. Id.

177. Texas v. Johnson, 491 U.S. 397, $411-12$ (1989) (citing Boos v. Barry, 485 U.S. 312, 321 (1988) (plurality opinion)).

178. However, the Court's willinguess to allow greater regulation of low value speech does have relevance to a determination of whether the Court would adapt current doctrine to uphold hostile environment law. See infra Part V.B.

179. See. e.g., Rankin v. McPherson, 483 U.S. 378, 386-87 (1987) (holding a threat to kill the President not protected); id. at 398 (Scalia, J., dissenting) (noting that extortion is not entitled to "any First Amendment protection at all').

180. Robinson v. Jacksonville Shipyards, Inc., 760 F. Supp. 1486, 1535 (M.D. Fla. 1991).

181. Strauss, supra note 8 , at 38-40.

182. R.A.V. v. City of St. Paul, 112 S. Ct. 2538, 2546 (1992) (citations omitted). 
mal threat. In quid pro quo harassment, the employer uses words to demand sexual favors in exchange for job benefits. Proscribing the discrimination carried out by the words, rather than the words themselves, is the ain of the law. Therefore, quid pro quo harassment may be classified as discriminatory conduct that raises no arguable First Amendment concerns.

In contrast, hostile environment harassment can be carried out entirely through expression, and it is the impact of the expression on the victim that is the target of the regulation. The distinction being drawn is that commonly referred to as the speech/conduct distinction. More precisely, the distinction is between laws ained at conduct, which might have an incidental effect on communication, and laws aimed at the effect of communication itself. $^{183}$

Finally, some have cited Pittsburgh Press Co. v. Pittsburgh Commission on Human Relations ${ }^{184}$ for the proposition that the Court has shown a willingness to uphold governmental restrictions on speech as discriminatory conduct. ${ }^{185}$ In that case the Court upheld a city ordmance prohibiting publication of want ads designated by sex. However, the Court did not rely on the fact that the speech carried out discrimination. Rather, the holding in Pittsburgh Press was expressly based on the fact that only "purely commercial advertising" was involved, which was then unprotected by the First Amendment. ${ }^{186}$ Thus, Pittsburgh Press cannot justify the regulation of sexually harassing speech.

In summary, because hostile environment regulation targets the communicative impact of the harassing speech and conduct, merely labeling hostile environment harassinent as conduct does not place it beyond the reach of the First Amendment. ${ }^{187}$

183. For example, in Debs v. United States, 249 U.S. 211 (1919), the Court upheld a conviction for obstructing war efforts by giving a public speech. The Court found that the 1917 Espionage Act punished the conduct of obstructing war efforts, and the speech merely served as evidence of that conduct.

184. 413 U.S. 376 (1973).

185. See, e.g., Robinson v. Jacksonville Shipyards, Inc., 760 F. Supp. 1486, 1535 (M.D. Fla. 1991) (asserting that holding sexually explicit pictures and verbal harassment to be discriminatory conduct was consistent with Pittsburgh Press); Brief Amicus Curiae of the American Civil Liberties Union and the American Jewish Congress, Harris v. Forklift Sys., 114 S. Ct. 367 (1993) (No. 92-1168).

186. 413 U.S. at 384-85. Three years after Pittsburgh Press the Court extended protection to purely commercial speech. See Virginia State Bd. of Pharmacy v. Virginia Citizens Consumer Council, Inc., 425 U.S. 748, 761-62 (1976). Perhaps the fact that commercial speech has been protected since soon after the Pittsburgh Press ruling accounts for the misreading of the significance of the case.

187. See Roberts v. United States Jaycees, 468 U.S. 609, 628 (1984) (holding that the application of an act which forced an organization to accept women as full, voting members was constitutional because the state's compelling interest in eradicating gender discrimination was unrelated to the suppression of expression and because the act restricted speech and associational rights no more than necessary to achieve that interest). Crucial to the holding was the fact that the state's interest was separable from the suppression of expression. This cannot be said of hostile environment regulation, where it is the communicative impact of speech and other expression that is the target of regulation. 


\section{Captive Audience Doctrine}

When speech is directed toward a "captive audience," an audience that would prefer to avoid exposure to the speech but cannot reasonably do so, the Court has taken into account the rights of the audience as a factor in favor of allowing speech restriction. Both courts ${ }^{188}$ and commentators ${ }^{189}$ have argued that the captive audience doctrine may be applied to allow regulation of speech in the workplace. However, the Court's prior captive audience cases do not support sucl an application. ${ }^{190}$

The Court first developed the doctrine in Kovacs v. Cooper, ${ }^{191}$ in which it upheld an ordinance that prohibited loud and raucous sound trucks from blasting noise in residential neighborhoods. The Court based its holding on the state's interest in protecting its citizens, who were "practically helpless" to escape the noise except through the protection of the ordinance. ${ }^{192}$ Since Kovacs, the Court has employed the captive audience doctrine almost exclusively where the unwilling audience was in the liome. In Rowan v. United States Post Office Dep't, ${ }^{193}$ the Court rejected a First Amendment challenge to a federal postal provision allowing individuals to direct the post office to refrain from delivering certain inaterials. In so holding, the Court said:

[T] he right of every person "to be let alone" must be placed in the scales with the right of others to communicate.

In today's coinplex society we are inescapably captive audiences for many purposes, but a sufficient measure of individual autonoiny must survive to permit every householder to exercise control over unwanted mail. ${ }^{194}$

Despite broad-reaching language, such as " $[\mathrm{n}]$ othing in the Constitution coinpels us to listen to or view any unwanted communication, whatever its

188. See, e.g., Robinson v. Jacksonville Shipyards, Inc., 760 F. Supp. 1486, 1535 (M.D. Fla. 1991) (holding that female workers were a captive audience in relation to the speech that created a sexually hostile work environment); Resident Advisory Bd. v. Rizzo, 503 F. Supp. 383, 402 (E.D. Pa. 1980) (holding that workers on jobsite were a captive audience, who were "powerless to avoid bombardment by derisive speech and noise" from protester-defendants' amplification system, short of giving up their jobs).

189. See, e.g., Balkin, supra note 120, at 386, 423-24 (arguing that few audiences are more captive than the average worker, and that the captive audience doctrine should be reinterpreted to permit regulation of workplace harassment); Strauss, supra note 8, at 35-37 (arguing that employees at work might qualify as a captive audience). But see Browne, supra note 73, at 516-20 (arguing that the captive audience doctrine does not support regulation of speech where the speaker has an equal right to be present); Volokh, supra note 70, at 1832-33 (arguing that the Court has never found employees in the workplace captive and that "there are good reasons for it not to do so").

190. This Comment proposes a modification of the captive audience doctrine that provides for its limited application in the workplace. See infra Part V. In this Section, I focus on whether the doctrine as currently applied by the Supreme Court has force in the workplace, and conclude that it does not.

191. 336 U.S. 77 (1949).

192. Id. at 87.

193. 397 U.S. 728 (1970).

194. Id. at 736 . 
merit,"195 the Rowan Court was explicit in relying on the fact that the unwanted mail was being blocked from the home, even citing the maxim that "a man's home is his castle."196

Similarly, FCC v. Pacifica Foundation ${ }^{197}$ held that the FCC did not offend the Constitution by forbidding the broadcast of George Carlin's twelve-minute inonologue entitled "Filthy Words." The Court rejected the speech's offensiveness as a sufficient reason for its suppression. ${ }^{198}$ Nonetheless, the Court allowed the regulation based on the facts that broadcasting has received "the inost limited First Amendment protection," extends into the privacy of the home, and is accessible to young children. ${ }^{199}$ The Court emphasized that an individual's right to be left alone in the privacy of the hoine "plainly outweigh[ed] the First Amendment rights of an intruder."200

More recently, in Frisby v. Schultz, ${ }^{201}$ the Court upheld a ban on focused picketing of individual homes. The state interest which justified the ban was "the protection of residential privacy."202 The Court explicitly himited its reasoning to the residence, cominenting on the "unique nature of the home,"203 and asserting that "the home is different." 204 The Court hinted that the captive audience doctrine might not apply at all outside the home: "'That we are often 'captives' outside the sanctuary of the home and subject to objectionable speech ... does not mean we must be captives everywhere." "205

In all of the "captive audience" cases discussed so far, the Court has based its reasoming on the value of privacy, and more specifically, on the nature of the home as the one sanctuary where the individual's right to privacy outweighs the right of other individuals to communicate unwanted messages. There is one case, however, that has been imterpreted to extend the captive audience doctrine outside the home, ${ }^{206}$ which in turn might justify the doctrine's current application to the workplace. In Lehman v. City of Shaker Heights, ${ }^{207}$ a plurality of the Court upheld a municipal policy that refused to allow political advertising cards on city buses, while at the same

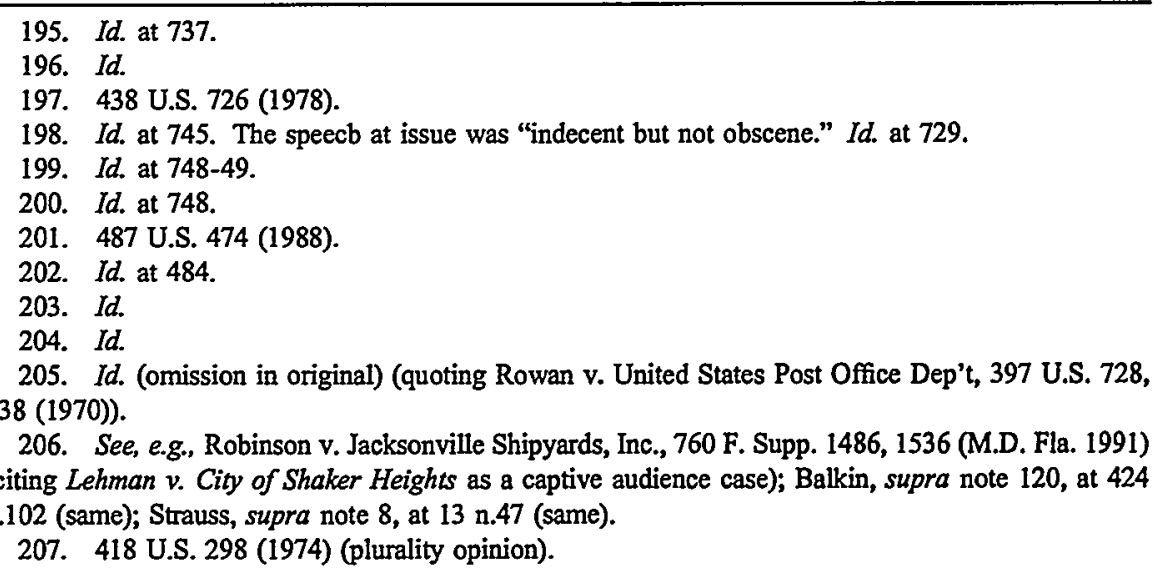


time allowing non-political advertising. The plurality opinion, made up of four justices, relied primarily on the fact that the city was engaged in a commercial venture when it provided public transportation, giving the city "discretion to develop and make reasonable choices concerning the type of advertising that may be displayed." 208

Because the case involved a city transit system's use of its own property-a nonpublic forum - the Court employed the minimal standard of scrutiny. It held that the policy governing access to the transit systein's advertising space was not "arbitrary, capricious or invidious,"209 and lence was constitutional. The plurality, in upholding the policy, inentioned the "risk of iniposing upon a captive audience."

The crucial fifth vote in Lehman came from Justice Douglas, whio relied more directly on the captive nature of the bus passengers: "In iny view the right of the commuters to be free from forced intrusions on their privacy precludes the city from transforming its vehicles of public transportation into forums for the dissemination of ideas upon this captive audience. .2211

By indicating that the Court at one time was willing to apply the concept of a captive audience outside the home, Lehman provides a possible starting point for defending sexual harassment regulations from First Amendinent challenges. However, the precedential value of the case is sharply linited by the fact that it involved a nonpublic forum created by the city goverument for a limited purpose. ${ }^{212}$ Moreover, the Court's reliance on the home as unique in Frisby, as well as the Court's rejection of the applicability of the doctrine in other cases involving speech outside of the

208. Id. at 303 .

209. Id.

210. Id. at 304.

211. Id. at 307 (Douglas, J., concurring). Although the issue was not before the Court, Justice Douglas indicated that commercial speech, which was allowed by the city, could be as offensive to a captive audience as political speech. Id. at 308 .

212. See Consolidated Edison Co. v. Public Serv. Comm'n, 447 U.S. 530, 539-40 (1980) (noting the limitations of Lehman to situations involving "the special interests of a government in overseeing the use of its property"). 
home, ${ }^{213}$ suggests that, as a doctrinal matter, the captive audience doctrine currently would not be applied to the workplace. ${ }^{214}$

In this Part, I have examined First Amendment doctrine as it relates to hostile environment sexual harassment. I have concluded that no existing exception to the principle of free speech is adequate to save hostile environment regulation. Three issues remain to be explored: whether the Court would adapt First Amendment doctrine to allow regulation of harassing speech; whether we should - as a nornative matter-allow infringement of traditional speech rights; and, if regulation should be allowed, what doctrinal justification should be employed, and exactly what form that regulation should take.

\section{IV}

\section{Should Harassing Speech Be Regulated?}

In considering whether First Amendment doctrine should be adapted to allow for regulation of speech that creates a sexually hostile workplace, it is important to consider the values on both sides of the equation-those underlying the goals of Title VII as well as those that have informed the development of First Amendment law. Moreover, the nature of the workplace should be considered in determining whether certain speech at the workplace should be suppressed. This Part departs from doctrine to engage in a nornative analysis of whether regulation should be allowed.

As mentioned in the Introduction, the atteinpt to eradicate discrimination through suppression of speech brings two fundainental values of our society into conflict: equality and freedom of expression. ${ }^{215}$ Some com-

213. See Cohen v. California, 403 U.S. 15, 21 (1971) (holding that the captive audience doctrine did not apply where the objectionable speech occurred in a courthouse corridor). The Court noted that while . . government may properly act in many situations to prohibit intrusion into the privacy of the home of unwelcome views ... [t] Constitution, to shut off discourse solely to protect others from hearing it is . . . dependent upon a showing that substantial privacy interests are being invaded in an essentially intolerable manner.

Id.; see also Erznoznik v. City of Jacksonville, 422 U.S. 205, 209-11 (1975) (holding that absent narrow circumstances involving the privacy of the home or a degree of captivity making it impracticable for the unwilling to avoid speech, the burden rests on the viewer to avoid the objectionable expression-in this case nudity on a drive-in screen). Although the language in Erznoznik was expansive, the case does not indicate the captive audience doctrine would currently be applied outside the home: the ordinance was not upheld in that case, nor has the doctrine been applied in any case except Lehman to uphold an ordinance outside the context of the home. The Erznoznik Court did, however, note that "each case ultimately must depend on its own specific facts," and seemed to support Lehman, noting that when "the degree of captivity makes it impractical for the unwilling viewer or auditor to avoid exposure," selective restrictions based on the offensiveness of speech may be permissible. Erznoznik, 422 U.S. at 209.

214. The extent to which the captive audience doctrine should be expanded to encompass workplace speech regulation is addressed infra Part V.

215. Notwithstanding commentators' claims otherwise, see, e.g., Lawrence, supra note 6, at 438 39 (reading Brown v. Board of Education, 347 U.S. 483 (1954), as a case about speech and the message of segregation); Volokh, supra note 70 , at 1844 , the Court has not been willing to "balance" these two interests. A recent example of the Court's trcatment of this conflict of values is R.A.V. v. City of St. Paul, Minn., 112 S. Ct. 2538 (1992), in which the Court struck down an ordinance desigued to eradicate 
mentators have argued that "[ $t]$ he best way to constitutionally protect these competing interests is to balance them directly."216 The eradication of gender discrimination in the workplace is a governmental interest that is undeniably quite strong, even "compelling." However, the principle of free speech has consistently been placed among our most valued rights. Balancing two such fundamental rights "directly" is no sinuple task. However, sonie observations may be made about the values underlying the First Amendment as they bear on equality in the workplace. For the sake of simplicity, I will group those values into the following broad categories: the marketplace of ideas rationale, the self-realization rationale, and the self-governance rationale.

\section{A. Marketplace of Ideas}

The "marketplace of ideas" rationale declares that through the exchange of divergent ideas in an open atmosphere the best ideas will rise to the top and gain popular consensus. ${ }^{217}$ Under this rationale, the value of free speech lies in a dialogue of differing ideas, beliefs, and values. In a public forum, this rationale should be $\mathrm{m}$ harmony with the goal of equality, because through dialogue the truth of the value of egalitarianism will einerge. 218

In the workplace, the power structure complicates the analysis. If the discriminatory ideas are directed to a group with less power, $m$ an environment that condones the power differential, the marketplace will likely not

racial discrimination. The Court conceded that the interest was a compelling one, and that the ordinance promoted the interest. "But the 'danger of censorship' presented by a facially content-based statute requires that that weapon be employed only where it is 'necessary to serve the asserted [compelling] interest.' " Id. at 2549 (alteration in original) (citations omitted). Because there were other means of fighting discrimination available to the city, the ordinance could not withstand scrutiny. With this "least means" analysis, the Court is able to avoid balancing equality against free speech. No matter how important equality is, there will virtually always be ways other than content-based speech regulations to advance it. So, while this Section balances free expression against equality in order to determine how much speech regulation should be allowed, I am not suggesting that the Court would (although perhaps it should) do the same.

216. Lawrence, supra note 6, at 446-47; see also Balkin, supra note 120, at 423 (noting the importance of reconciling the compcting interests of egalitarianism and the principle of content neutrality in specch regulation); Volokh, supra note 70, at 1843-47 (arguing that the interest that harassment law serves must be balanced against the value of the free speech suppressed by harassment law).

217. The phrase "marketplace of ideas" has heen adapted, of course, from Justice Holmes' famous statement that the "ultimate good desired is hetter reached by free trade in ideas-that the best test of truth is the power of the thought to get itself accepted in the competition of the market." Abrams v. United States, 250 U.S. 616, 630 (1919) (Holmes, J., dissenting).

218. This is, admittedly, a rather utopian view of speech in a public forum. Many things may operate to skew the market and call into doubt whether freedom of speech really is truth producing. See TRIBE, supra note 106, $\S 12-1$, at 768 (questioning whether the marketplace analogy is really apt, and citing sources that do the same); Lawrence, supra note 6 , at 466-68 (suggesting that most people of color are skeptical that the marketplace rationale will produce acceptance of the best ideas, and that equality is a precondition to free specch). 
operate as assumed. ${ }^{219}$ Assuming at least some sexually harassing speech does not invite or even allow dialogue, ${ }^{220}$ leading to a market failure, the marketplace of ideas rationale suggests that such speech should be subject to some amount of regulation. For example, sexually derogatory epithets, pornographic pinups, and similar expression seem less likely to mvite dialogue than statements about women's (lack of) abilities and (in)equality.

While an argument examining whether speech invites dialogue logically seems to extend to justify regulation of all "stifling" speech, the "stifling" nature of the speech alone does not justify regulation. To allow regulation of all speech that discourages the listener from responding, in whatever context that speech might occur, would subject all deeply offensive speech to censorship-a result at odds with the idea that the marketplace, rather than the government, should determine what speech has value. It is in the context of the workplace, where other factors such as power differentials and economic pressures ${ }^{221}$ come into play, that the marketplace of ideas rationale seeins particularly weak. In this setting then, we may decide that speech that is not directed at producing dialogue should be subject to regulation to achieve the goal of increased workplace equality.

The process of distinguishing speech that does from speech that does not contribute to the marketplace of ideas must encoinpass many considerations. As Professor Strauss points out, "sexist speech conveys a inessage that would be lost if the speech were cleansed of its ugliness."222 The inessage Professor Strauss refers to is the "deplorable nature of such

219. See Strauss, supra note 8, at 28 (arguing that the "perfect marketplace, if it exists at all, does not exist with respect to sexist speech"). Moreover, it could be argued that the pervasivencss of sexism causes the market to malfunction by skewing the way we evaluate women's specch. For a similar argument focused on racial discrimination, see Lawrence, supra note 6, at 468-71.

220. For example, the harasser in Rabidue used the terms "pussy," "cunt," "fat ass," and "tits." Rabidue v. Osceola Refining Co., 584 F. Supp. 419, 423 (E.D. Mich. 1984), aff'd, 805 F.2d 611 (6th Cir. 1986), cert. denied, 481 U.S. 1041 (1987). These words are not of the sort that seem likely to invite truth-producing dialogue. A number of commentators have noted the silencing effect of hate speech. See, e.g., Cass R. Sunstein, Words, Conduct, Caste, 60 U. CHr. L. Rev. 795, 812 (1993) (noting that, although it is not a sufficient reason for regulating such speech, "[m]any forms of spccch do indeed have silencing effects"); Scott J. Catlin, Note, A Proposal for Regulating Hate Speech in the United States: Balancing Rights Under the International Covenant on Civil and Political Rights, 69 Notre DaMe L. REv. 771, 792 (1994) (noting the silencing effect of hate speech); Kim M. Watterson, Note, The Power of Words: The Power of Advocacy Challenging the Power of Hate Speech, 52 U. PrTr. L. Rev. 955, 974 (1991) (noting the silencing effect of hate speech and arguing that because of the silencing effect, regulation can be justified as a means of opening the market); $c f$. Catharine A. MacKinnon, Not a Moral Issue, 2 YALE L. \& PoL'Y REv. 321, 340 (1984) (arguing that the assumption underlying the First Amendment that speech is actually free absent government interference is false-that women have bcen socially silenced by pornography); Marianne Wesson, Girls Should Bring Lawsuits Everywhere . . . Nothing Will Be Corrupted: Pornography as Speech and Product, 60 U. Cri. L. Rev. 845, 857-58 (1993) (arguing that, in the context of pomography, one "shortcoming of the marketplace modcl is that it does not account for the 'silencing' effect of some speech').

221. The Court took note of the significance of the economic realities of the workplace in permitting a limited regulation of employer speech in the labor context. See NLRB v. Gissel Packing Co., 395 U.S. 575, 617 (1969).

222. Strauss, supra note 8 , at 28. 
thoughts and ideas."223 There is arguably some value, then, in allowing even the most offensive speech. If all offensive language is cleansed, the offensiveness of the underlying message carried by that language may be overlooked. But, if the most offensive speech were removed only from the workplace, and left unimpeded in the rest of society, the offensiveness of the underlying message would not likely be lost.

\section{B. Self-Realization}

A second broadly-defined value underlying free speech is that of selfrealization. ${ }^{224}$ Speech may be valuable simply because it allows the speaker to express himself, regardless of whether the speech contributes to the marketplace of ideas or to self-governance. Freedom of speech is an aspect of mdividual liberty and dignity, a good in and of itself. ${ }^{225}$ This principle would seem to protect all speech, because the freedom to speak is valuable without reference to the content or the result of the speech.

In a vacuum, the self-realization rationale would protect sexually harassing speech: the speech has value because it allows the harasser to express himself freely. However, to the extent that the speech infringes on the ability of the listener to express herself fully, ${ }^{226}$ and to the extent the speech harms the listener's imdividual liberty and dignity, ${ }^{227}$ the self-realization rationale cannot serve as a comprehensive reason for the protection of harassing speech. Suppressing such speech results in the same overall societal level of self-expression as allowing the speech. The only difference is $m$ who does the expressing, the victim or the harasser.

The interests on both sides would depend on the context and nature of the speech. In most instances, an insulting statement-such as "you women are all whores"-allows the speaker to express himself, but does not infringe too greatly on the hearer's dignity, ability to express herself, or

223. Id.

224. For an argument that self-realization is the only value underlying the First Amendment, and that it encompasses other values traditionally associated with the First Amendment, see Martin H. Redish, The Value of Free Speech, 130 U. PA. L. REv. 591, 593 (1982).

225. See, e.g., Herhert v. Lando, 441 U.S. 153, 183-84 n.l (1979) (Brennan, J., dissenting in part) (arguing that free speech is "intrinsic to individual dignity" in a society in which "the autonomy of each individual is accorded equal and incommensurate respect').

226. See Susan H. Williams, Feminist Jurisprudence and Free Speech Theory, 68 TuL. L. Rev. 1563, 1578 (1994).

[T] he silencing effect of hate speech may be particularly severe in employment settings in which the targets of the speech often are extremely isolated and economieally vulnerable. The silencing effect may be real but less severe in the college campus context and, perhaps, even less severe in a traditional public forum, such as a street or a park. If hate speech causes this silencing effect, then it forfeits some of its claim to First Amendment value, but how much of the value is lost may well be a matter that can only be determined in a very context-specific way.

Id.

227. See, e.g., Richard Delgado, Words That Wound: A Tort Action for Racial Insults, Epithets, and Name-Calling, 17 HARv. C.R.-C.L. L. Rev. 133, 143 (I982) (noting that in the context of racial hate speeeh, "a racial insult is always a dignitary affront"). 
ability to walk away without responding. Even though insulting and offensive, this type of expression cannot be regulated consistent with First Amendment values.

In the workplace, power differentials and economic forces give harassing speech more potential to damage the listener than in most other areas. As discussed below, the histener will often be essentially captive to harassing speech or conduct. ${ }^{228}$ While the speaker's interest in expressing himself remains the same, the hearer's interest grows to the extent that her ability to avoid the harassment herself is limited, and to the extent that her dignity is infringed. While the self-realization rationale would protect almost all speech, it might allow some regulation of harassing speech in the workplace context.

\section{Self-Governance}

The self-governance theory describes the First Amendment as protectmg the "thinking process of the community" 229 or the quality of public debate in order to ensure "the voting of wise decisions." 230 The implication of self-governance as the rationale underlying the First Amendment is that speech not contributing to the goal of quality public decisionmaking does not deserve protection.

Autonomy is said to be irrelevant to the value of self-governance..$^{231}$ Therefore, an individual's right to speak, even on matters of political inportance, is not paramount. What is inportant is that public debate be rich, "not that everyone shall speak, but that everything worth saying shall be said."232 Under this analysis, it seeins unlikely that workplace speech would ever be protected. It contributes very little to the public debate, because the audience is limited. If "everything worth saying" is already

228. See infra notes 263-64 and accompanying text.

229. Alexander Meikiejohn, Political Freedom: The Constitutional Powers of the People 27 (1965). Meiklejohn considered the First Amendment to be "an expression of the basic American political agreement that, in the last resort, the people of the United States shall govern themselves. To find its meaning, therefore, we must dig down to the very foundations of the self-governing proccss." Hearings Before the Subcomm. on Constitutional Rights of the Senate Comm. on the Judiciary. 84th Cong., 1st Sess., Pt. 1, at 1 (1955) (testimony of Alexander Meiklejohn), reprinted in AlEXANDER MetKIEJOHN: TEACHER of Freedom 229, 232 (Cynthia S. Brown ed., 1981) [hereinafter AleXander MEIKLEJOHN (testimony)].

230. MeIKLEJoHN, supra note 229, at 26; see, e.g., Robert H. Bork, Neutral Principles and Some First Amendment Problems, 47 IND. L.J. 1, 30-31 (1971) (identifying the core of the First Amendment as the "discovery and spread of political truth"); Owen M. Fiss, Freedom and Feminism, 80 GEo. L.J. 2041, 2044 (1992) (analyzing pornography related prohibitions from the viewpoint that "the First Amendment is an instrument of democratic self-governance"); Cass R. Sunstein, Preferences and Politics, 20 PHIL. \& PUB. AfF. 3, 28 (1991) (identifying the meaning of the First Amendment as the promotion of "democratic deliberation").

231. MEIKLEJOFN, supra note 229, at 55. For an argument that Meikiejohn and other proponents of this theory are misguided in their rejection of autonomy as necessary to true democratic sclfgovernment, see Robert Post, Meiklejohn's Mistake: Individual Autonomy and the Reform of Public Discourse, 64 U. Cozo. L. REv. 1109 (1993).

232. MEIKLEJOHN, supra note 229 , at 26. 
being said in society in general, this theory would not protect one's right to say it again, or say it in a place where contribution to public debate is so limited.

However, the principle behind the self-governance rationale can be broadened to encompass enhanced protection of all political speecl1. ${ }^{233}$ The Supreine Court has repeatedly acknowledged the special place political expression occupies in terms of First Amendment protection. ${ }^{234}$ Under this broader formulation, the self-governance rationale would justify providing greater protection for workplace speech that relates to politics and to inatters of self-governance than to other workplace speecl.

The question that arises under the self-governance rationale is what speecli should be deeined to contribute to wise voting, or more broadly, to the enrichment of public debate. Speech about an election campaign is the most obvious case of speech that contributes to enlightened selfgovernance. In the workplace, sucl1 speecl, even when contributing to a sexually hostile environment, should be protected. ${ }^{235}$

Speecl that contributes to self-governance is not limited to speech directly about politics. Speecl on "public issues" must be protected, because as we vote we "judge the wisdoin or folly of suggested ineasures."236 Moreover, literature must be protected, because it allows the electorate to become educated for self-governance. ${ }^{237}$ Workplace discussions of public or social issues would, then, be protected. Literature at the workplace would also be protected, althougl pornographic visual images would not be. Thus, the self-governance rationale would protect liarassing speecli beyond that whicl concerns politics directly.

233. See Thomas I. Emerson, The System of Freedom of Expression 7 (1970).

[F]reedom of expression is essential to provide for participation in decision making by all members of society. This is particularly significant for political decisions. Once one accepts the premise of the Declaration of Independence-that governments "derive their just powers from the consent of the governed"-it follows that the governed must, in order to exercise their right of consent, have full freedom of expression both in forming individual judgments and in forming the common judgment.

Id. While Professor Emerson notes that this principle carries beyond the arena of politics, it has enhanced application to political decisions.

234. See, e.g., Boos v. Barry, 485 U.S. 312,318 (1988) (noting that "classically political speech" is at the core of the First Amendment); Dun \& Bradstreet,.Inc. v. Greenmoss Builders, Inc., 472 U.S. 749, 759 (1985) (subjecting rcgulation of political speeeh to most exacting scrutiny); NAACP v. Claiborne Hardware Co., 458 U.S. 886, 915 (1982) ("[S]peeeh to protest racial discrimination is essential political speech lying at the core of the First Amendment.") (quoting Henry v. First Nat'l Bank, 595 F.2d 291, 303 (5th Cir. 1979)).

235. For example, where opponents in an election were a man and a woman, the statement "women are too stupid to govern cffectively," if part of a pervasive pattern of harassment of women, could contribute to a sexually hostile environment. However, this statement should be protected by the First Amendment, and so should be excluded from consideration when determining whether a hostile environment has been created.

236. AleXANDer MEikiejohn (testimony), supra note 229, at 239.

237. Alexander Meiklejohn, The First Amendment Is an Absolute, 1961 Sup. CT. Rev. 245, reprinted in part in ALEXANDER MEIKIEJOHN: TEACHER OF FREEDOM, supra note 229, at 246, 250, 255 56. 
$* * * *$

The underlying goal of achieving equality in the workplace could be relied on as justifying coinplete suppression of all workplace speech that has a differential impact on woinen-all speech that contributes even in a small way to an environment less hospitable to women. ${ }^{238}$ However, we are reluctant as a society to allow speech to be regulated, particularly based on content, even when equality is the goal of the regulation. ${ }^{239}$ This Part has atteinpted to show, by reference to traditional free speech values, that some regulation of harassing speech in the workplace is justified. In particular, the most offensive or harmful harassing speech should be regulated in the workplace. This speech contributes little to the inarketplace of ideas, and infringes too much on the captive listener to justify protection based on the value of self-realization. However, no matter how offensive, workplace speech that contributes to self-governance should remain protected at all times.

The following portion of this Comment suggests a modification of current First Amendment doctrine that allows for regulation of workplace harassment. The Comment then offers an adaptation of the current hostile environment harassment standard which better accords with the doctrinal modification suggested, and First Amendment principles generally.

\section{V \\ Expanding the Captive Audience Doctrine (with SOME LIMITATIONS)}

As shown in Part III.D, the captive audience doctrine currently has hittle or no force outside the home. ${ }^{240}$ However, it seens the most pronnising candidate for being adapted to allow the appropriate amount of hostile environment sexual harassment regulation. ${ }^{241}$ It has two features in particu-

238. That the goal of equality could carry this far is illustrated by the way one court recently construed the objective or reasonableness component of hostile environment law:

The purpose of Title VIl is not to import into the workplace the prejudices of the community, but through law to hberate the workplace from the demeaning influence of discrimination, and thereby to implement the goals of human dignity and economic equality in employment. The reasonableness of sex-hased conduct is determined from the perspective of climinating "the entire spectrum of disparate treatment of men and women" in employment.

King v. Hillen, 21 F.3d 1572, 1582 (Fed. Cir. 1994) (quoting Meritor Savings Bank v. Vinson, 477 U.S. 57,64 (1986)).

239. See supra note 215 .

240. For a suggestion that this should remain the case, see TRIBE, supra note $106, \S 12-16$, at 919 ("[T]he attempt to single out some images or ideas for complete suppression outside the protected enclave of the home seems ultimately incompatible with the first amendment premise that awareness can never be deemed harmful in itself.").

241. See Marcy Strauss, Redefining the Captive Audience Doctrine, 19 Hastmas Const. L.Q. 85, 106 (1991). Professor Strauss' article engages in an in-depth critique and analysis of the captive audience doctrine as it has developed. She proposes a method of employing the doctrine that she argues carries out the underlying goals of the doctrine more effectively than the Court's mode of analysis.

Professor Strauss would almost eertainly apply the captive audience doctrine in the workplace in some instances. See Strauss, supra note 8, at 11 (rcgulation of sexist speech in the workplace may be 
lar that recommend it: (1) it allows content-based distinctions; and (2) it takes the hearer's rights and the context of the speech into account.

The Court has employed the captive audience doctrine to allow otherwise impermissible content-based distinctions. The Court noted this nearly unique feature of the captive audience doctrine in Erznoznik:

But when the government, acting as censor, undertakes selectively to shield the public from some kinds of speech on the ground that they are more offensive than others, the First Amendment strictly limits its power. Such selective restrictions have been upheld only when the speaker intrudes on the privacy of the hoine, or the degree of captivity makes it impractical for the unwilling viewer or auditor to avoid exposure. ${ }^{242}$

When the government protects a captive audience from speech because the speech is offensive, it is necessarily making a judgment that is based on the content of the speech. ${ }^{243}$ The fact that the Court has allowed regulation based on offense to the hearer under the captive audience doctrine makes the doctrine the best suited for saving hostile environment law.

The Court in Erznoznik grounded the ability of the government "to shut off discourse solely to protect others from hearing it" in the privacy rights of the unwilling recipient of the speech. ${ }^{244}$ In fact, as noted above, every case discussed that employed the captive audience doctrine relied on the privacy rights of the unwilling audience. ${ }^{245}$ This feature of the captive audience doctrine allows courts to take the rights and perspective of the speech "victin" into account. Moreover, context becomes inportant: speech that is offensive inay be regulable in some circumstances, but remain protected in situations in which the unwilling listener inay simply avoid the speech. Thus, the nature of the workplace becomes an inportant factor in the constitutional analysis.

justified where the speech is made with discriminatory intent, where it causes a direct discriminatory effect, or where the offended listener constitutes a captive audience). However, Professor Strauss would not apply the captive audience doctrine to undirected speech in the workplace. Id. at 36-37. For speech not specifically directed at the alleged victim of harassment, the burden of avoiding the speech generally would remain on the offended party. Id. Moreover, Professor Strauss advocates that courts employ a case-specific balancing method each time they use the captive audience doctrine. Strauss, Redefining the Captive Audience Doctrine, supra, at II6. I would reject both Professor Strauss' limitation of the applicability of the captive audience doctrine to directed speeeh in the workplace, and her case-by-case method of applying the doctrine. First, even undirected speech, when pervasive and severe enough, should be regulable to further the goals of Title VII. Second, concerns of doctrinal clarity and judicial administrability suggest that clearer lines should be drawn than those suggested by Professor Strauss.

242. Erznoznik v. City of Jacksonville, 422 U.S. 205, 209 (I975) (footnote omitted) (first citation omitted) (citing Rowan v. United States Post Office Dep't, 397 U.S. 728 (I970); Lehman v. City of Shaker Heights, 4I8 U.S. 298 (1974)).

243. See FCC v. Pacifica Found., 438 U.S. 726, 748-50 (1978) (applying the captive audience doctrine to George Carlin's "Filthy Words" monologue based on the offensiveness of the words to the hearers).

244. Erznoznik, 422 U.S. at 210 (quoting Cohen v. Cahfornia, 401 U.S. 15, 21 (197I)).

245. See supra notes 191-211 and acconpanying text. 


\section{A. The Captive Audience Doctrine and the Workplace}

The captive audience doctrine can be extended, consistently with the principles underlying it, to the workplace. Moreover, extending the captive audience doctrine to the workplace does not raise the "slippery slope" concern that, once extended beyond the hoine, there will be no logical stopping point.

The Court has refused to apply the captive audience doctrine outside of the hoine because the objectionable speech was not shown to invade "substantial privacy interests . . . in an essentially intolerable inanner." 246 In Cohen v. California, the Court refused to apply the captive audience doctrine to uphold the petitioner's conviction for wearing a jacket bearing the words "Fuck the Draft" in a corridor of the Los Angeles County courthouse. ${ }^{247}$ The intolerable invasion of substantial privacy requirement was not inet because "[t]hose in the Los Angeles courthouse could effectively avoid further boinbardment of their sensibilities simply by averting their eyes."248 In other words, while the privacy of unwilling viewers might be invaded to a certain extent, ${ }^{249}$ there was no captive audience because the viewers could limit such an invasion by ending their exposure to the speech. The Court was doubtless correct: in Cohen, there was no evidence that people were powerless to avoid the petitioner's conduct, or even that they did in fact object to the expressive conduct. ${ }^{250}$

In Erznoznik v. City of Jacksonville, the ordinance at issue proscribed the showing of a novie or other exhibit containing nudity on the screen of a drive-in theater if the screen was visible from any public street or other public place..$^{251}$ The Court held that the captive audience doctrine could not save the ordinance because "[t]he ordinance seeks only to keep these films from being seen froin public streets and places where the offended viewer readily can avert his eyes."252 In other words, the invasion of privacy was slight because, as im Cohen, the intrusion could easily be limited. Moreover, one has very limited privacy on a public street, so any invasion is less troubling.

246. Cohen, 403 U.S. at 21.

247. Cohen was convicted under a statute that prohibited "maliciously and willfully disturb[ing] the peace or quiet of any neighborhood or person . . . by . . offensive conduct." Id. at 16 (quoting Cat. PENAL CODE $\S 415$ ) (alterations in original).

248. Id. at 21 .

249. The Court seemed to acknowledge some level of privacy interests on the part of the unwilling viewers. See id. at 22 ('[S]ome unwilling 'listeners' in a public building may have been briefly exposed to [Cohen's jacket] ....").

250. Id. at 22 .

251. Erznoznik v. City of Jacksonville, 422 U.S. 205, 206-07 (1975) (quoting JACKSONVILLE, FLA., MUNICIPAI CODE $\S 330.313$ ). The particular instances of nudity covered by the ordinance were "the human male or female bare buttocks, human female bare breasts, [and] human bare pubic areas." Id. at 207 (quoting JaCKSONVILlE, FLA., Municipal CODE § 330.313).

252. Id. at 212 . 
The workplace, however, is neither a public corridor nor a public street. In terms of a recognizable privacy right, the Court in Cohen and other cases has inade clear that the nature of the place where the speech or expressive conduct occurs is inportant in determining the scope of the privacy interest. ${ }^{253}$ While it makes sense that a courthouse corridor falls closer to Central Park (or a public street) than it does to the home in terms of privacy rights, the same is not true of the workplace.

In the context of the Fourth Amendment right against unreasonable searches, the Court has recognized that a privacy right may exist in the workplace. In order for a search to come under Fourth Amendment scrutiny, there inust be a "reasonable expectation of privacy."254 In $O^{\prime}$ Connor $v$. Ortega, ${ }^{255}$ the Supreme Court rejected unanimously the argument that governmental employees can never have a reasonable expectation of privacy in their workplace. ${ }^{256}$ Both the plurality and the dissent, in total eight members of the Court, relied on the societal expectation of privacy in the workplace. ${ }^{257}$

In discussing the privacy expectation at the workplace, the plurality in Ortega compared the expectation to that which exists in the home. ${ }^{258}$

253. See, e.g, id. at 209 (noting that the captive audience doctrine has been employed to allow content-based regulation "only when the speaker intrudes on the privacy of the home," or "the degree of captivity makes it impractical for the unwilling listener ... to avoid exposure"); Cohen v. Cahifornia, 403 U.S. 15, 21-22 (1971) ("[W] hile it may be that one has a more substantial claim to a recognizable privacy interest when walking through a courthouse corridor than, for example, strolling through Central Park, surely it is nothing like the interest in being free from unwanted expression in the confines of one's own home.").

254. Katz v. United States, 389 U.S. 347, 360 (1967) (Harlan, J., concurring). The reasonable expectation of privacy language has since been adopted by the Court as the test. Terry v. Ohio, 392 U.S. 1,9 (1968).

255. 480 U.S. 709 (1987).

256. The plurality of Justices O'Connor, Rehnquist, White, and Powell found that the reasonable expectation of privacy extended at least to Dr. Ortega's desk and file cabinets, but held that the question of whether any given public employee had a reasonable expectation of privacy must be addressed on a case-by-case basis. Id. at 718 (plurality opinion). Justice Scalia would hold that the offices of government employees are covered by the Fourth Amendment, without a case-by-case inquiry. Id. at 731 (Scalia, J., concurring). Finally, the dissenters found that "Dr. Ortega had an expectation of privacy in his office, desk, and file cabinets." Id. at 732 (Blackmun, Brennan, Marshall, Stevens, J.J., dissenting). Thus, while the plurality advocated a case-by-case approach, five members of the Court insisted that a reasonable expectation of privacy existed in a public employee's office.

The Ortega Court held that Fourth Amendment rights exist in the public workplace. However, the Court also held that those rights may be limited by the institutional goals of the public-sector workplace. Five members of the Court held, based on the "operational realities of the workplace," id. at 717, that the Fourth Amendment did not require a warrant for public employer intrusions into the constitutionally protected privacy interests of the employees, where the intrusions were for non-investigatory purposes, or were work-related (as opposed to criminal) misconduct investigations. Id. at 722-23 (plurality opinion); id. at 732 (Scalia, J., concurring).

257. Both the plurahity and the dissent quote the same passage in Oliver v. United States, 466 U.S. 170,178 n.8 (1984), to show the privacy interest at the workplace. Ortega, 480 U.S. at 716 (plurality opinion) (finding expectation of privacy in one's workplace is "based upon societal expectations that have deep roots in the history of the [Fourth] Amendment"); id. at 737 (Blackmun, J., dissenting) (same).

258. Id. at 716 (plurality opinion). 
While the Fourth Amendment conception of privacy as protecting against physical searches of one's property is distinct from a conception of privacy that would justify suppression of offensive speech, it is instructive. The similarity recognized by the Ortega court between the privacy right at hoine and that at the workplace suggests the captive audience doctrine may be extended to the workplace based on the privacy interests of the workers. ${ }^{259}$

The Court does not justify the expectation of privacy it recognizes in the workplace, except to say that it exists (at one level or another) and that it has its roots in societal expectations and in history. One possible justification is grounded in consistency and intuition: to say that there is a Fourth Amendment privacy right in the workplace, but no privacy right for First Amendment (or other) purposes, seems wrong on both counts. There are additional reasons for recognizing a workplace privacy right for purposes of the captive audience doctrine.

First, it seems undisputable that a large percentage of inost people's time is spent at the workplace. The right to privacy has been termcd "the right to be let alone."260 In places whcre inost people spend a large portion of their time, it nnakes sense that we would want to recognize a right to be left alone. The percentage of time spent in the workplace is large enough to bring the workplace closer to the home than to a public park in terms of privacy interests. Of course, time spent im a location does not create a privacy right by itself. Homeless people living in a public park do not necessarily gain greater privacy than people who walk through the park. ${ }^{261}$ However, people may liave legitimate expectations of privacy in the workplace, with the time spent as one factor among others.

Additionally, there may be a sense of identification or possessiveness involved with one's workplace. People may feel at ease there in a way similar to the ease felt at home. If society wants to encourage such feelings about workplaces, recognizing a privacy interest at the workplace may be one way to do so. ${ }^{262}$

A final factor weighing in favor of extending the captive audience doctrine to the workplace is that there would not likely be a "slippery slope"

259. Similarity between rights at work and at home is also recognized in the Model Penal Code's limitation of the no retreat rule to the home and the workplace. MPC $\S 3.04$ (2)(b)(ii)(A).

260. See, e.g., Samuel D. Warren \& Louis D. Brandeis, The Right to Privacy, 4 HARv. L. Rev. 193, 205 (1890) (describing the right to privacy as a "right of the individual to be let alone" in the context of protection from publication of private matters).

261. Note that this is consistent with the Fourth Amendment analogy presented above. A homeless person would not likely be provided any greater protection against searches than a person walking through the park. In fact, many possessions of a homeless person may be in plain view for purposes of Fourth Amendment protection.

262. It is interesting to note that two fairly reeent Alabama Supreme Court cases have recognized a cause of action for invasion of privacy in cases involving sexual harassment of an employee by an employer. For a discussion of these cases as they relate to workplaee privacy issues, see David N. King, Note, Privacy Issues in the Private-Sector Workplace: Protection From Electronic Surveillance and the Emerging "Privacy Gap," 67 S. CAL. L. REv. 441, 464-67 (1994). 
problem. In other words, the nature of the workplace is sufficiently distinct to allow the principled application of the captive audience doctrine there, but nowhere else outside the home. For many, work is a necessity. Not only are people at their jobs a large percentage of their waking lours, but they often have little choice about the matter. There exists an element of economic coercion, ${ }^{263}$ which forces people to remain at the workplace even under adverse conditions. The costs and uncertainties associated with leaving are high enough to create a degree of captivity that distinguishes the workplace from all other places in society, with the possible exception of the home. In fact, there is arguably a lesser degree of "captivity" in the home, where there is no penalty for leaving; the captive audience doctrine as applied to the home seems more accurately to reflect society's belief that a person should not have to leave her home to avoid offensive speech. The high degree of captivity associated with the workplace provides a principled basis on which to extend the captive audience doctrine to the workplace and no further. ${ }^{264}$

Before concluding this Section, it should be recognized that there is another type of privacy interest at stake in this discussion: the interest of an employee (or employer) who wants the freedom to paste a pimup to the mside of his or her lunch pail, locker, or briefcase. This type of privacy interest is distinct from that discussed above, but it does operate to suggest limits on our ability to regulate employee speech and behavior based on the privacy interests of other employees. For personal spaces such as lockers and briefcases, it seems that the privacy right of the party owning or controlling that space should prevail, regardless of the offense others might experience if they saw what was posted in that personal space. For the workplace environment generally, however, the privacy interests of those

263. The Court has taken the economic dependence of employees into account in First Amendment analysis. See NLRB v. Gissel Packing Co., 395 U.S. 575, 617 (1969) (stating that any balancing of the employer's First Amendment rights against the employees' right to associate freely in the labor context must "take into account the economic dependance of the employees on their employers").

As an example of a relatively mild instance of economic coercion, consider a female attorney who worked through law school and landed a prestigious job. If she suffers harassment, and assuming there were no laws to protect against such harassment, she may be hesitant to leave something she worked so hard to attain. While it could be argued that she is responsible for the choice to stay, the response is that she should not be put to that choice. She is not as free to "walk away" from the harassment as is a person strolling through Central Park. For her, to walk away is to give up something of great value. Furthermore, even if she did walk away from her job, in this hypothetical there are no laws restricting harassing speech (or expressive conduct) at any workplacc. Therefore, she has no guarantee of a better work environment at a future job. It is easier to envision the more extreme cases of economic coercion: anyone who must bring home a check each month to avoid eviction or foreclosure will find it very hard to walk off of the job.

264. It could be argued that the campus environment has equal "coercive" forces that make it difficult for a victim of harassment to leave. In that environment, however, with the exception of the classroom, there are no physical places in which a student must remain or else face sanctions. An analysis of the application of the eaptive audience doctrine to campus harassment is beyond the scope of this Comment. 
who prefer not to be exposed to speech and conduct that creates a sexually hostile environment is paramount.

\section{B. Extension of the Captive Audience Doctrine to Allow Regulation of Harassment}

The Court conceivably could adopt the extension of the captive audience doctrine advanced above. As Laurence Tribe has noted, "the Court is beginning to construct a inulti-level edifice with several intermediate categories of less-than-coinplete constitutional protection for certain kinds of expression."265 In allowing regulation of what is often referred to as "lowvalue speech," the Court has not always acknowledged that new levels of protection are being created. Rather, the Court has adapted existing exceptions to First Amendment protection in ways that it likely would not have done had the speech at issue not been "low value" speech.

For example, the "near obscene" cases show that the Court is willing to be generous in upholding regulations that limit sexually explicit (though not obscene) speech. In Young v. American Mini Theatres, Inc. ${ }^{266}$ the Court upheld an "anti-skid row ordinance" regulating the placement of adult theaters and bookstores. The Court explained, "Even though the First Amendment protects communication in this area from total suppression, we hold that the State may legitimately use the content of these [sexually explicit] materials as the basis for placing thein in a different classification from other motion pictures."267 Because the ordinance regulated only where, and not whether, the films could be seen, the Court upheld the content-based regulation with a lesser state interest than that usually required. The Court allowed a "reasonable opportunity to experiment" with the means to protect the character of the city's neighborhoods. ${ }^{268}$ In other words, the Court essentially allowed content-based regulation under a less demanding test than strict scrutiny. The Court justified its decision by pointing out that the regulation only limited the places in which the adult materials could be seen. However, time, place, and manner regulations are generally not allowed if based on content. Thus, in a case mvolving "low value" speech, the Court allowed a regulation it would not have under a straightforward application of existing doctrine.

The Court retreated froin the position taken in American Mini Theatres ten years later when it decided Renton $v$. Playtime Theatres, Inc. ${ }^{269}$ In that case, the Court again upheld a zoning ordinance applicable to adult theaters. In Renton, however, the Court held that the ordinance was a content-neutral

265. TRRB, supra note $106, \S 12-18$, at 930 . Tribe is highly critical of this trend. See id. at 939 40.

266. 427 U.S. 50 (1976).

267. Id. at 70-71.

268. Id. at 71.

269. 475 U.S. 41 (1986). 
time, place, and manner regulation, aimed solely at the "secondary effects" of the presence of adult theaters on the surrounding community. ${ }^{270}$

The characterization of an ordinance applicable only to (non-obscene) adult materials as non-content-based is highly questionable. The Court conceded that at first glance the ordinance, "like the ordinance in American Mini Theatres, does not appear to fit neatly into either the 'content-based' or the 'content-neutral' category."271 However, the Court upheld the district court's determination that the "predominate" intent of the city council concerned the secondary effects on the community of the presence of adult theaters, not the content of the films themselves. ${ }^{272}$ That the ordinance was " "justified without reference to the content of the regulated speeclr" "273 was sufficient for the Court to find the ordinance content neutral. In fact, the justification found acceptable by the Court was the experience of Seattle - and not Renton - that adult theaters have a harmful effect on the area in which they are located. ${ }^{274}$

Notably, the Court quoted the following passage from American Mini Theatres: " ' [] $\mathrm{t}$ is manifest that society's interest in protecting this type of expression is of a wliolly different, and lesser, magnitude than the interest im untrammeled political debate ...." "275 This passage belies the notion that the ordinance at issue, and the Court's analysis of that ordinance, is not based on content.

In a more recent case imvolving nude dancing, several members of the Court signed on to opmions noting that, although nude dancing was expressive conduct protected by the First Amendinent, it was at the margin of constitutional protection. ${ }^{276}$ Unsurprisingly, the Court upheld the regulation at issue under various levels of scrutiny less demanding than the strict scrutiny commonly applied to regulation of protected speech.

Thus, the Court, without always being willing to say so, applies a lesser standard to sexually explicit speech. The Court applies a lesser stan-

270. Id. at $47-48$.

271. Id. at 47.

272. Id. at 48.

273. Id. (quoting Virginia State Bd. of Pharmacy v. Virginia Citizens Consumer Council, Inc., 425 U.S. 748, $771(1976))$.

274. Id. at 51-52.

275. Id. at $49 \mathrm{n} .2$ (alteration in original) (quoting Young v. American Mini Theatres, Inc., 427 U.S. 50,70 (1976) (plurality opinion)).

276. Barnes v. Glen Theatre, Inc., 501 U.S. $560,565-66$ (1991) (plurality opinion); id. at 584 (Souter, J., concurring). The plurality, applying $O^{\prime} B r i e n$, id. at 565-66, and Justice Souter, applying a secondary effects analysis, id. at 584 , upheld a regulation banning public nudity as applied to erotic dancing. Justice Scalia provided the fifth vote for upholding the regulation, concurring on the ground that a general law regulating conduct and not specifically aimed at expression is not subject to any First Amendment scrutiny at all. Id. at 572 . 
dard to other types of "low value" speech as well: commercial speech, ${ }^{277}$ non-obscene offensive speech, ${ }^{278}$ and defamation ${ }^{279}$ are several examples.

Thus, given the Court's more lenient treatment of regulation of "low value" speech, the Court would likely allow regulation of sexually harassing speech. ${ }^{280}$ Moreover, it is likely that the Court would do so by adapting a current doctrine. The captive audience doctrine, for the reasons set out above, seems the best candidate. ${ }^{281}$

\section{Offensive Political Speech}

When the Court has applied the captive audience doctrine, it has done so expansively, even upholding regulations that reach political speech. George Carlin's "Filthy Words" monologue was political in its protest of censorship. ${ }^{282}$ The would-be-picketers in Frisby v. Shultz were antiabortion protesters ${ }^{283}$ - there is little speech that is more clearly political. The traditional applicability of the doctrine to pohtical speech raises concern about its application to the workplace. If the captive audience doctrine were extended to the workplace, it could be used to justify suppression of political speech. Because such speech is valuable under any theory of the First Amendinent, and because it is rightly viewed as the most important speecli to protect, it is undesirable to employ a First Amendinent exception to the workplace in a way that allows political speech to be regulated.

The captive audience doctrine could be applied in a way that excepts political speech. The normative analysis einployed im Part V suggests that political speecli should be given a higher level of protection than other

277. See Central Hudson Gas \& Elec. Corp. v. Public Serv. Comm'n, 447 U.S. 557, 562-63 (1980).

278. See FCC v. Pacifica Found., 438 U.S. 726, 743 (1978) ("[W]hile some [references to exeretory and sexual organs and activities] may be protected, they surely lie at the periphery of First Amendment concern.").

279. See Gertz v. Robert Welch, Inc., 418 U.S. 323, 340-41 (1974).

280. Note that it is unlikely the Court would apply the analysis utilized in Renton and hold that hostile environment law is not content-based. Hostile environment law cannot be viewed as aimed at "secondary effects" of speccli or conduct. While one could argue that a lostilc workplace is a secondary effect of the harassing speech, and the target of the regulation, such an analysis cannot withstand scrutiny. The workplace is hostile precisely because of the message of the speech - this is very different from the Renton concern with deteriorating neighborhoods. The communicative effect of the speech is not a secondary effect.

281. In R.A.V. v. City of St. Paul, Minn., Justice White, joined in his concurrence by Justices Blackmun, $O$ 'Counor, and Stevens, suggested that the captive audience doctrine might justify regulation of hate speech given the proper construction and circumstances. $112 \mathrm{~S}$. Ct. at $2560 \mathrm{n} .13$ (1992) (White, J., concurring) ("Although the First Amendment protects offensive speceh, it does not require us to be subjected to such expression at all times, in all settings. We lave held that such expression may be proscribed when it intrudes upon a 'captive audience.' ... However, because of the manner in which the Minnesota Supreme Court construed the St. Paul ordinance, [that issue is] not before us in this case.") (citations omitted).

282. Pacifica Found., 438 U.S. at 729 (" $[$ Carlin] began [his monologue] by referring to his thoughts about 'the words you couldn't say on the public, ah, airwaves, um, the ones you definitely wonldn't say, ever.' ").

283. 487 U.S. 474,476 (1988). 
workplace speech. Society's interest in robust debate is infringed only minimally by the suppression of sexist slurs or pornographic pinups in the workplace. However, society has a far greater interest in robust debate of political ideals, including gender equality. ${ }^{284}$ While it inay be a difficult task for courts to determine what constitutes political speech, it should be no inore difficult than application of the Connick standard of speech regarding inatters of public concern. ${ }^{285}$

Applying the captive audience doctrine to the workplace but excepting pohtical speech balances the coinpeting interests involved. If Title VII were adapted to accord with this inodification of the captive audience doctrine, ${ }^{286}$ the inost valuable workplace speech-political speech-would receive protection, while other speech that contributes to a hostile environinent would be regulable.

\section{The Underinclusiveness Problem}

The strongest argument advanced against the application of the captive audience doctrine to the workplace is that, based on the rationale of protecting a captive workforce from offense, the regulation of hostile environment harassinent is undermclusive because it limits only certain forms of offensive speech in the workplace. ${ }^{287}$

The rationale of the captive audience doctrine as applied to the workplace is to protect the workforce not from simple offense, but froin the harm of a discriminatory environment. Therefore, it is defensible to regulate certain, though not all, offensive speech at the workplace. The right not to suffer the distinct harm of workplace inequality is implicated to a greater degree by certain forms of offensive speech: speech that is reasonably and actually offensive to a certain subgroup at the worksite. Because the captive audience doctrine allows consideration of the rights of the unwilling

284. Professor Strauss' suggested reformulation of the captive audience doctrine supports this distinction. Professor Strauss suggested a three-factor test for courts to use in their application of the captive audience doctrine. The three factors were as follows:

First, how great is the justification for protecting an unwilling audience? Second, how difficult is it for the listener to avoid the speech, and would avoiding the speech achieve the goals of the captive audience doctrine? Finally, how significant is the infringement on the First Amendment right to freedom of expression?

Strauss, supra note 241 , at 116 . Her third factor, if taken to encompass all of the values underlying the First Amendment, supports giving greater proteetion to political speech (assuming the other factors weigh equally).

285. 461 U.S. 138 (1983). For a description of the Connick standard of speech relating to matters of public concern, see supra notes 82-83 and aecompanying text. Connick requires that when a public employee is sanctioned for speech of public concern, the court should balance the speech against any detrimental cffect on the efficiency of the workplace, rather than automatically protecting the speech. Id. at 142. I would protect political speech in the private workplace from government-imposed regulation in all instances.

286. See infra Part VI.

287. See Browne, supra note 73, at 5I8-19; Volokh, supra note 70, at I842-43. 
audience and the societal interest in free speech, it becoines defensible to regulate some, and not all, offensive speech.

"[S]o long as the nature of the content discrimination is such that there is no realistic possibility that official suppression of ideas is afoot," 288 it is permissible to regulate some, but not all, proscribable speech. When properly understood, the application of the captive audience doctrine to harassinent is not actually underinclusive in a way that raises the threat of governmental suppression of certain ideas. While not all speech that might contribute to an environment that adversely affects one gender is regulated, the justification for selective regulation does not suggest preference of certain viewpoints over others. Rather, the justification seeks to regulate all speech that contributes to a sexually hostile environment, except speech that contributes to self-governance. The latter category of speech is excepted without reference to the viewpoint of the speaker; no danger of censorship is posed by such an exception. Finally, it is important to note that the infringement on speech expressing competing viewpoints would be greater if all speech that contributes to a hostile environment were reached by harassment regulation. Under this analysis, a carefully-crafted hostile environment sexual harassinent standard would not be underinclusive in any suspect sense.

\section{VI \\ A New Standard}

The current hostile environment harassment standard, ${ }^{289}$ as explained above, suffers from problems of vagueness and possibly overbreadth. ${ }^{290}$ It is the aim of this Part to modify the standard to conforn to the requirements of the vagueness and overbreadth doctrines more closely, and to reflect the captive audience doctrine's application to the workplace. My proposed

288. R.A.V. v. City of St. Paul., Minn., 112 S. Ct. 2538, 2547 (1992). The Court's analysis of the line separating permissible and impermissible underinclusive regulations meanders somewhat. The Court asserts that, although commercial speech may be regulated for reasons unrelated to the message of the speech, "a State may not prohibit only that commercial advertising that depicts men in a demeaning fashion." Id. at 2546. However, the Court coneludes that regulation of "sexually derogatory "fighting words" " is permissible as part of Title VII's general goal of eliminating sexual discrimination in employment practices. Id. Sexually derogatory fighting words are a segment of fighting words defined with reference to the message underlying the speech, and thus to regulate such words because they are "sexually derogatory" seems to run counter to the rest of the Court's opinion in R.A.V. Despite this seeming inconsistency, the underlying rule is clear: some, but not all proscribable speech may be regulated so long as the selectivity of the speech restriction is not such that it raises the danger of government eensorship of eertain viewpoints or subjects. Id. at 2545-47.

289. The current standard reads:

Unwelcome sexual advances, requests for sexual favors, and other verbal or physical conduct of a sexual nature constitute sexual harassment when ... such conduct has the purpose or effect of unreasonably interfering with an individual's work performance or creating an intimidating, hostile, or offensive working environment.

29 C.F.R. \& 1604.11(a) (1994).

290. See supra Purt II.B.4. 
standard does not begin with a blank slate, but rather incorporates and adapts the current standard:

(1) Hostile environment sexual harassment violates $\S 703$ of Title VII under the following circumstances:

(a) There is verbal or physical conduct in the workplace which is either of a sexual nature or based on the sex of the recipient; and

(b) Such verbal or physical conduct is sufficiently severe or pervasive either to hinder a reasonable employee of the same sex's work performance significantly, or to affect significantly the mental, emotional, or physical well-being of a reasonable employee of the same sex. ${ }^{291}$

(2) The existence of the foregoing conditions will be determined by looking at the totality of the circumstances.

(3) The conduct need not be intentionally harassing to constitute harassment.

(4) In determining the pervasiveness of harassing speech based on sex, or harassing speech of a sexual nature, political speech will be exempted from consideration.

This proposed standard is doubtless imperfect. However, it is less vague than the current standard. It avoids any reliance on adjectives such as "abusive" or "hostile." Conduct described as harassing speech in the proposed standard must be such that it would affect the job performance or well-being of a reasonable person of the same sex. The proposed standard attempts to make hostile environment sexual harassment law as objective as possible, ${ }^{292}$ while carrying out its goals of eradicating gender discrimination in the workplace.

The standard is also less overbroad than the current standard. The liability structure remams the same, with the einployer being liable for a hostile work environment even when it is created solely by the speech of others. However, there is less imcentive for an employer to overregulate speech when the standard is narrowly defined and objective. More significantly, this standard exempts speech that contributes to self-governance, so that the employer would not be encouraged to automatically censor all offensive speech. Rather, the inost valuable speech will receive First Amendment protection. In turn, this protection will remind employers that there is a speech interest that must be considered in crafting workplace speech policies.

291. This portion of the standard is modeled, in part, after a proposed standard advanced in the Brief Amicus Curiae of the American Civil Liberties Union and the American Jewish Congress in Support of Petitioner, Harris v. Forklift Sys., Inc., 114 S. Ct. 367 (1993) (No. 92-1168).

292. As stated by Justice O'Connor in Harris, hostile environment law "by its nature cannot be ... a mathematically precise test." $114 \mathrm{~S}$. Ct. at 371 . 
The proposed standard also resolves some of the circuit splits over the application of hostile environment law. ${ }^{293}$ The standard adopts a reasonable person of the same sex standard. Analyzing a harm that is based on the sex of the victim from a genderless reasonable person standard does not adequately address the current problem of workplace harassment. The Ninth Circuit described the need for an objective standard that imcorporates the victim's gender as follows:

If we only exammed whether a reasonable person would engage in allegedly harassing conduct, we would run the risk of reinforcing the prevailing level of discrimination. Harassers could continue to harass merely because a particular discriminatory practice was common, and victims of harassment would have no remedy.

We therefore prefer to analyze harassment from the victim's perspective. A complete understanding of the victim's view requires, among other things, an analysis of the different perspectives of men and women. Conduct that many men considcr unobjectionable may offend many women. ${ }^{294}$

The proposed standard expressly rejects a requirement of intent on the part of the harasser. As the Nimth Circuit has pointed out, a reasonablc person of the same sex standard is inconsistent with a requirement of intent. $^{295}$ A requirement of intent generally would result im liability only where a reasonable person of the harasser's sex also would find the conduct to rise to the level of harassment.

The proposed standard incorporates the Harris liolding that the conduct need not seriously affect the psychological well-being of the victim. ${ }^{296}$ However, the harassment must affect either the victim's well-being, or her ability to perform her job. This requirement is an attempt to ensure that only conduct and speech that is actually harmful is proscribed, and to create as objective a standard as is possible. Finally, the proposed standard inakes clear that the speech or conduct does not have to be sexual to be reached by hostile environment law. ${ }^{297}$ Conduct and speech based on the sex of the recipient may contribute to a sexually hostile environment.

The standard also immunizes political speech from liability. Definimg political speech precisely is, of course, a difficult task. As discussed earlier, this Comment considers speech that contributes to self-governance to be "political speech."298 Political speech includes speech directly on politics, on public and social issues, and on such broader concepts as literature. ${ }^{299}$

293. See supra Part I.B.

294. Ellison v. Brady, 924 F.2d 872, 878 (9th Cir. 1991).

295. See supra text accompanying note 40 .

296. See supra text accompanying notes $42-44$.

297. See supra text accompanying notes $46-47$.

298. See supra Part IV.C.

299. See supra Part IV.C. 
By exempting political speech, the standard strikes a compromise between First Amendment interests and equality interests.

\section{CoNCLUSION}

The conflict between the principles of free speech and equality is one that demands attention, forces careful thought, and offers no easy solutions. This Comment has suggested changes in First Amendment doctrine and hostile environment law that are designed to serve both goals. The solution offered is admittedly miperfect, but that is a necessity absent abandonment of the speech or equality principle. In the area of hate speech in general, and hostile environment sexual harassment im particular, the two principles are at odds. My hope is that I have proposed a compromise that accommodates both principles to the greatest degree possible. 
